BEACHES, SUNSHINE, AND PUBLIC-SECTOR PAY:

THEORY AND EVIDENCE ON AMENITIES AND RENT EXTRACTION BY GOVERNMENT WORKERS

Jan K. Brueckner

David Neumark

Working Paper 16797

http://www.nber.org/papers/w16797

\author{
NATIONAL BUREAU OF ECONOMIC RESEARCH \\ 1050 Massachusetts Avenue \\ Cambridge, MA 02138 \\ February 2011
}

We thank Rainald Borck, Kitt Carpenter, and Albert Solé Ollé for helpful comments. The views expressed herein are those of the authors and do not necessarily reflect the views of the National Bureau of Economic Research.

NBER working papers are circulated for discussion and comment purposes. They have not been peerreviewed or been subject to the review by the NBER Board of Directors that accompanies official NBER publications.

(C) 2011 by Jan K. Brueckner and David Neumark. All rights reserved. Short sections of text, not to exceed two paragraphs, may be quoted without explicit permission provided that full credit, including (C) notice, is given to the source. 
Beaches, Sunshine, and Public-Sector Pay: Theory and Evidence on Amenities and Rent Extraction by Government Workers

Jan K. Brueckner and David Neumark

NBER Working Paper No. 16797

February 2011, Revised May 2012

JEL No. J45,J48,J61,R10

\begin{abstract}
The absence of a competitive market may enable public-sector workers to extract rents from taxpayers in the form of high pay, especially when public-sector workers are unionized. On the other hand, this rent extraction may be suppressed by the ability of taxpayers to vote with their feet, leaving jurisdictions where public-sector workers extract high rents. However, although migration of taxpayers may limit rent-seeking, public-sector workers may be able to extract higher rents in regions where high amenities mute the migration response. We develop a theoretical model that predicts such a link between public-sector wage differentials and local amenities, and we test the model's predictions by analyzing variation in these wage differentials and amenities across states. We find that public-sector wage differentials are, in fact, larger in the presence of high amenities, with the effect stronger for unionized public-sector workers who are likely better able to exercise political power in extracting rents. The implication is that the mobility of taxpayers is insufficient to prevent rent-seeking behavior of public-sector workers from leading to higher public-sector pay.
\end{abstract}

Jan K. Brueckner

Department of Economics

UCI

3151 Social Science Plaza

Irvine, CA 92697

jkbrueck@uci.edu

David Neumark

Department of Economics

University of California at Irvine

3151 Social Science Plaza

Irvine, CA 92697

and NBER

dneumark@uci.edu 


\title{
Beaches, Sunshine, and Public-Sector Pay: Theory and Evidence on Amenities and Rent Extraction by Government Workers
}

by

\author{
Jan K. Brueckner and David Neumark*
}

\section{Introduction}

Public-sector pay is not set in competitive markets. Public-sector unionization is high (Visser, 2006), and public-sector unions are strong and active politically (DiSalvo, 2010). As a consequence, the pay of public-sector workers is likely to reflect, in part, the extraction of rents from taxpayers. Indeed, the potential for public-sector workers to influence pay (and employment) has long been noted by labor economists (Freeman, 1986).

The issue of public-sector pay has come to the fore lately, in part because of state budget woes. The media and blogosphere are replete with stories about overpaid public-sector workers, from prison guards in California, ${ }^{1}$ to teachers and other public-sector workers in New Jersey, ${ }^{2}$ to unionized public-sector workers generally. ${ }^{3}$ Not surprisingly, the reality is more complex. Looking at the public sector in the aggregate reveals that, in recent years, public-sector workers are not overpaid. Although for both men and women, data from 2000 reveal a positive pay gap between the public and private sectors (about 11 percent for men and 20 percent for women), in earnings regressions with the usual controls, there is a negative pay differential for working in the public sector of 6 percent for men, and no pay differential for women (Borjas, 2002). ${ }^{4}$ On the other hand, researchers have pointed to pensions and other benefits for public-sector workers that are very generous, particularly when account is taken of underfunded pension liabilities and how they are calculated (Biggs, 2010a, 2010b; DiSalvo, 2010). In addition, the power of public-sector unions, as exemplified by the extensive union involvement in efforts to recall governors in California (Malanga, 2010), suggests that substantial scope for rent extraction may exist. ${ }^{5}$

Freeman (1986), however, argued against the ability of public-sector unions to extract high rents, using a Tiebout-sorting view of the world: "Citizens unhappy with [the] level of public 
services can move elsewhere, reducing the taxable population and thus the ability to pay public sector wages. Mobility places great constraints on public-sector union bargaining power" (p. 51). But this view need not rule out specific cases where public-sector workers are overpaid. Indeed, casual inference based on the stories cited above suggests that high public-sector pay may be a phenomenon confined to particular states - specifically those states well endowed with the amenities often emphasized by urban economists. Facing a high willingness-to-pay on the part of potential residents to live in a high-amenity state, public-sector workers may have more leeway for rent extraction, leading to a link between public-sector wages and amenities. The purpose of the present paper is to test for such a link.

Initial suggestive evidence for this wage-amenity connection is contained in Figure 1, which plots state-level public-sector wage residuals (representing the wage component not explained by the usual controls) against state-level private-sector wage residuals. ${ }^{6}$ The solid line has slope equal to one, so that points on the line represent a state in which the public-sector and privatesector wage premia for the state are equal. While most of points are in fact below the line, note the identities of the states above the line - states where the public-sector premium is larger than the private-sector premium and hence where public-sector workers are "overpaid." These states have warm weather (California and Florida), low rainfall (Nevada), a coastal location (e.g., New York, New Jersey, and Rhode Island), and large, dense urban areas (New York, New Jersey, and California). Thus, Figure 1 suggests that rent extraction may be occurring in places where people like to live.

We develop and test a model that explores this hypothesis. Building on existing work on the public sector (e.g., O'Brien, 1992; Rose and Sonstelie, 2010; Zax and Ichniowski, 1988), we presume that public-sector workers - especially unionized ones - have some ability to determine their pay (and perhaps also their levels of employment) through the political process. Consistent with Freeman's argument, we would expect that this political power would face limitations, because if public-sector workers extract rents (and thus taxes) that are too high relative to the level of desired publicly-produced goods and services, then taxpayers will vote with their feet, depriving public-sector workers of the tax base from which to extract rents. ${ }^{7}$ However, in locations with strong amenities, public-sector workers may have more ability to 
extract rents, as these amenities drive wedges between the utility of taxpayers in different locations that public-sector workers can exploit.

Our stylized theoretical model takes an extreme viewpoint by assuming that the public sector is fully controlled by its workers, who have the power to set the public-good level as well as taxes, which cover both the nonlabor cost of the good as well as their own high wages. These workers set taxes along with the level of the public good to maximize the public-sector wage (and thus their utility), taking the induced migration between regions into account. The key results of the model connect the wage levels of both public- and private-sector workers to the level of a region's amenities. As captured in Figure 1, the main empirical hypothesis is that amenities raise the public-sector wage relative to the private-sector wage, a consequence of the improved rent-extraction potential in a high-amenity region. The model also predicts that public-sector wages should be higher in an absolute sense in high-amenity regions.

Our model is related to the large literature on tax competition, in which local governments make fiscal decisions taking into account the footloose nature of business investment, which is deterred by high local taxes. Here, though, the focus is on mobile private-sector workers rather than mobile business capital. Within this literature, which is surveyed by Wilson (1999), the paper is most closely connected to models of tax competition by rent-seeking rather than benevolent local governments, as exemplified by Edwards and Keen (1996). Our framework also shares elements of models in the Roback (1982) tradition, which show how amenity differences affect interregional patterns of wages and house prices.

The model's predictions are tested using Current Population Survey data. We estimate standard log wage regressions that include a public-sector wage differential, a wage differential associated with local amenities, and an interaction between these two differentials. The interaction coefficient reveals that the public-sector wage differential is larger in the presence of strong amenities, as predicted by the theory. The results are remarkably robust. They emerge for public-sector workers overall, and for two large groups of public-sector workers that are the focus of much attention with regard to pay: teachers and prison guards (or correctional officers). Moreover, the evidence is particularly strong for unionized public-sector workers, who are presumably better able to exercise political power to extract rents. 
The paper's empirical work bears a close resemblance to empirical studies in the Roback tradition. A common approach to implementing the Roback (1982) model, as exemplified by Blomquist, Berger, and Hoehn (1988), is to estimate two regressions relating individual wages and house prices to regional amenity levels. ${ }^{8}$ The results of these regressions are then merged to generate estimates of consumer amenity valuations, building on the theory. Our key regression is similar to a Roback-style wage regression, except that it includes, along with the usual amenity measures, terms that interact the amenity levels with a public-worker dummy variable. The coefficients of the (uninteracted) amenity levels give the usual impact of amenities on private-sector wages, while the interaction coefficients give the differential amenity effect on public-sector wages, which the theory predicts is positive. Moreover, if unionized workers have more ability to extract rents, then their amenity interaction coefficient should be larger than the coefficient for public-sector workers as a whole. The empirical results strongly conform to all these expectations. In addition, they confirm the prediction that amenities raise the absolute level of public-sector wages.

Section 2 of the paper develops the theoretical model, while section 3 describes the data. Section 4 presents the empirical work, and section 5 offers conclusions.

\section{Model}

\subsection{Basic analysis}

The economy has two regions, with region 1 having a positive amenity level and region 2 a zero level (a normalization). Region 1's amenity could have a consumption component (denoted $a$ ) as well as a component that raises worker productivity (denoted $b$ ). There are two groups of residents in each region: private-sector workers, who are mobile across regions, and public-sector workers, who are immobile. ${ }^{9}$ This latter group has captured control of the public sector in each region, and thus has the ability to set the public-good level as well as taxes. ${ }^{10}$ Taxes pay for the cost of the public good while also covering rent extraction by the public-sector workers, in the form of excessive wages. For simplicity, public-sector workers do not consume the good they produce, so that only private workers consume the public good and pay taxes. As seen below, relaxation of this assumption has no effect on the results. In 
setting the level of the good as well as taxes, public workers play a Nash game across regions, taking account of the fact that their decisions affect the location choices of private workers. For simplicity, the model is initially developed without consumption of housing, which plays a key role in the usual Roback-style framework. Once the basic conclusions are derived, housing is introduced with little effect on the results.

Let $z_{i}$ denote the public-good level in region $i$, and suppose that the good is a publicly produced private good with cost per unit normalized to unity. Per capita cost is then just $z_{i}$, being independent of the size of the private-worker population. This cost represents only the cost of nonlabor inputs, not including the wages of public-sector workers, which are a separate expense covered by rent extraction. Note that, with the size of the public work force fixed in each region, an increase in $z_{i}$ is achieved solely by raising non-labor inputs, whose costs are assumed to rise in proportion to $z_{i}$.

Let $x_{i}$ denote consumption of the private good and $a_{i}$ denote the consumption amenity level in region $i$. We assume that the preferences of private workers are quasi-linear and given by

$$
x_{i}+a_{i}+v\left(z_{i}\right)
$$

In (1), suitable measurement allows to the amenity to enter utility in linear fashion, just like $x_{i}{ }^{11}$ Since public-sector workers do not consume the public good (an assumption relaxed below), their utility is instead equal to the amenity plus $x$ consumption.

Let $L_{i}$ denote the number of private-sector workers in region $i$. The economy's total number of private workers is fixed at $\bar{L}$, so that $L_{1}+L_{2}=\bar{L}$. Letting $b_{i}$ denote the level of the production amenity in region $i$, private-sector output in the region is given by $f\left(L_{i}\right)+b_{i} L_{i}$, with the wage equal to $f^{\prime}\left(L_{i}\right)+b_{i}\left(f^{\prime \prime}<0\right.$ holds $)$. The production amenity thus affects productivity in an additive fashion. ${ }^{12}$ Profit from private production is assumed to flow to agents outside the economy.

Let $R_{i}$ denote public-sector rent extraction per private-sector worker. Since taxes per private-sector worker are then equal to $z_{i}+R_{i}$, the private-sector worker's budget constraint 
is $x_{i}+z_{i}+R_{i}=f^{\prime}\left(L_{i}\right)+b_{i}$. Utility for a region-1 worker is then

$$
f^{\prime}\left(L_{1}\right)+b_{1}-z_{1}-R_{1}+a_{1}+v\left(z_{1}\right)
$$

Since the amenity components enter additively in (2), they can be collapsed into a single term, denoted $A$, with $b_{1}=\alpha A$ and $a_{1}=(1-\alpha) A$, where $0 \leq \alpha \leq 1$. A pure consumption amenity corresponds to $\alpha=0$, while a pure production amenity corresponds to $\alpha=1 .{ }^{13}$ A "composite" amenity has an intermediate value of $\alpha$. Although most of the analysis is unaffected by the nature of the amenity, region 1's private-sector wage, which equals $f^{\prime}\left(L_{1}\right)+\alpha A$, depends on its source.

Migration between the regions must equate utilities. Recalling that no amenity is present in region 2 , the equilibrium condition

$$
f^{\prime}\left(L_{1}\right)-z_{1}-R_{1}+A+v\left(z_{1}\right)=f^{\prime}\left(\bar{L}-L_{1}\right)-z_{2}-R_{2}+v\left(z_{2}\right)
$$

must hold. Note that, in the presence of housing, cost-of-living differences between regions would enter (3), as seen in the extension below. Condition (3) determines $L_{1}$ and thus the division of population as a function of the decision variables $z_{1}, R_{1}, z_{2}$, and $R_{2}$, as well as $A$. Holding the decisions variables constant, an increase in $A$ will shift workers toward region 1 , with $L_{1}$ rising. Although an increase in region 1's amenity thus entices workers to live there, holding the $z$ 's and the $R$ 's fixed, our interest lies in exploring how a stronger pull of the amenity, as reflected in a larger $A$, affects the levels of these decision variables, as chosen by rent-seeking public-sector workers.

Recognizing the dependence of $L_{1}$ on the decision variables, public workers in region $i$ choose $z_{i}$ and $R_{i}$ to maximize their income, taking the other region's choices as given in Nash fashion. To characterize the solution to this problem, consider region 1's decisions and note that differentiation of (3) yields

$$
\begin{aligned}
& \frac{\partial L_{1}}{\partial z_{1}}=\frac{1-v^{\prime}\left(z_{1}\right)}{f^{\prime \prime}\left(L_{1}\right)+f^{\prime \prime}\left(\bar{L}-L_{1}\right)} \\
& \frac{\partial L_{1}}{\partial R_{1}}=\frac{1}{f^{\prime \prime}\left(L_{1}\right)+f^{\prime \prime}\left(\bar{L}-L_{1}\right)}<0 .
\end{aligned}
$$


Greater rent extraction in region 1 naturally reduces its population, while the effect of $z_{1}$ depends on the sign of the numerator in (4), which determines whether the good is over or underprovided relative to the efficient level (an increase in $z_{1}$ raises $L_{1}$ when the good is underprovided, with $v^{\prime}>1$ ).

Total rent extraction by public workers in region 1 equals $L_{1} R_{1}$. With the number of such workers fixed at $M$ in each region, rent per public-sector worker (which corresponds to the public-sector wage) equals $L_{1} R_{1} / M$. Thus, maximizing the public-sector wage means maximizing $L_{1} R_{1}$ by proper choice of $z_{1}$ and $R_{1}$, viewing $z_{2}$ and $R_{2}$ as fixed. The first-order condition for $z_{1}$ is ${ }^{14}$

$$
\frac{\partial L_{1} R_{1}}{\partial z_{1}}=R_{1} \frac{\partial L_{1}}{\partial z_{1}}=R_{1} \frac{1-v^{\prime}\left(z_{1}\right)}{f^{\prime \prime}\left(L_{1}\right)+f^{\prime \prime}\left(\bar{L}-L_{1}\right)}=0
$$

using (4). This condition reduces to $v^{\prime}\left(z_{1}\right)=1$, which implies that the public-good is chosen efficiently (with marginal benefit equal to the unitary marginal cost). With the public-good level set in socially optimal fashion, private-sector workers are encouraged to live in region 1, allowing more rent to be extracted by public-sector workers. Let $z^{*}$ denote the optimal public-good level, which is independent of the level of amenities (an outcome that follows from quasi-linear utility).

The first order condition for $R_{1}$ is

$$
\frac{\partial L_{1} R_{1}}{\partial R_{1}}=L_{1}+R_{1} \frac{\partial L_{1}}{\partial R_{1}}=L_{1}+\frac{R_{1}}{f^{\prime \prime}\left(L_{1}\right)+f^{\prime \prime}\left(\bar{L}-L_{1}\right)}=0
$$

using (5). ${ }^{15}$ Rearranging (7) allows $R_{1}$ to be written in terms of $L_{1}$ :

$$
R_{1}=-L_{1}\left[f^{\prime \prime}\left(L_{1}\right)+f^{\prime \prime}\left(\bar{L}-L_{1}\right)\right]
$$

Public workers in region 2 maximize $\left(\bar{L}-L_{1}\right) R_{2}$ by choosing $z_{2}$ and $R_{2}$, and analogous solutions emerge. The public-good level satisfies $v^{\prime}\left(z_{2}\right)=1$, thus equaling $z^{*}$, and $R_{2}$ is given by

$$
R_{2}=-\left(\bar{L}-L_{1}\right)\left[f^{\prime \prime}\left(L_{1}\right)+f^{\prime \prime}\left(\bar{L}-L_{1}\right)\right]
$$


The Nash-equilibrium level of $L_{1}$ can be found by using (8) and (9) to eliminate $R_{1}$ and $R_{2}$ in the migration condition (3). Making these substitutions yields

$$
f^{\prime}\left(L_{1}\right)+L_{1}\left[f^{\prime \prime}\left(L_{1}\right)+f^{\prime \prime}\left(\bar{L}-L_{1}\right)\right]+A=f^{\prime}\left(\bar{L}-L_{1}\right)+\left(\bar{L}-L_{1}\right)\left[f^{\prime \prime}\left(L_{1}\right)+f^{\prime \prime}\left(\bar{L}-L_{1}\right)\right],
$$

where the terms involving $z^{*}$ cancel. This equation determines $L_{1}$ as a function of $A$.

\subsection{The effect of amenities on public- and private-sector wages}

Using (10), the main questions of interest can be addressed: how do amenities affect publicand private-sector wages? The first step is differentiate (10), which yields

$$
\frac{\partial L_{1}}{\partial A}=-\left\{3 f^{\prime \prime}\left(L_{1}\right)+3 f^{\prime \prime}\left(\bar{L}-L_{1}\right)+\left(2 L_{1}-\bar{L}\right)\left[f^{\prime \prime \prime}\left(L_{1}\right)-f^{\prime \prime \prime}\left(\bar{L}-L_{1}\right)\right]\right\}^{-1} .
$$

Despite the apparent ambiguity of the sign of (11) (a consequence of the presence of $f^{\prime \prime \prime}$ ), the expression can be signed using a stability condition for the equilibrium. However, the subsequent discussion is simpler when it relies on a local analysis around the symmetric outcome (where $A=0$ ), in which case the sign of (11) is clear from inspection. With $A=0, L_{1}=\bar{L} / 2$ holds and the last term in (11) drops out, so that

$$
\frac{\partial L_{1}}{\partial A}=-\frac{1}{6 f^{\prime \prime}(\bar{L} / 2)}>0
$$

Thus, region 1 (the high amenity region) has more private-sector workers than region 2. Note that the derivative in (11) gives the change in $L_{1}$ when a small amenity advantage is introduced in region 1 , starting from a situation where neither region has amenities.

The effect of $A$ on the private-sector wage is driven by a change in the marginal product of labor as a result of migration. In the case of a pure consumption amenity, which does not directly affect the marginal product, the private-sector wage in region 1 falls as in-migration depresses $f^{\prime}$. But with a composite amenity, a direct productivity effect interacts with the migration effect, making the change in the marginal product ambiguous and dependent on the 
strength of the direct effect. Specifically, since the wage equals $f^{\prime}\left(L_{1}\right)+\alpha A$, the effect of $A$ is given by

$$
f^{\prime \prime} \frac{\partial L_{1}}{\partial A}+\alpha=f^{\prime \prime}\left(-\frac{1}{6 f^{\prime \prime}}\right)+\alpha=\alpha-\frac{1}{6}
$$

using (12). So while the private-sector wage falls with $A$ in the case of a pure consumption amenity, where $\alpha=0$, the wage rises with $A$ in the case of a pure production amenity, where $\alpha=1$ and (13) equals 5/6. With a composite amenity, the wage falls only if the consumption component is large, with $\alpha<1 / 6$.

Since region 2 loses workers, the private-sector wage rises there regardless of the nature of region 1's amenity. The wage derivative is equal to $f^{\prime \prime} \partial L_{2} / \partial A=-f^{\prime \prime} \partial L_{1} / \partial A=1 / 6$, using (12).

To find the effect of amenities on the public-sector wage, (8) can be used to write

$$
\frac{L_{1} R_{1}}{M}=-\frac{L_{1}^{2}}{M}\left[f^{\prime \prime}\left(L_{1}\right)+f^{\prime \prime}\left(\bar{L}-L_{1}\right)\right]
$$

Differentiation then yields

$$
\frac{\partial L_{1} R_{1} / M}{\partial A}=-\frac{1}{M}\left\{2 L_{1}\left[f^{\prime \prime}\left(L_{1}\right)+f^{\prime \prime}\left(\bar{L}-L_{1}\right)\right]+L_{1}^{2}\left(f^{\prime \prime \prime}\left(L_{1}\right)-f^{\prime \prime \prime}\left(\bar{L}-L_{1}\right)\right]\right\} \frac{\partial L_{1}}{\partial A}
$$

Evaluating (15) at the symmetric equilibrium using (12) yields

$$
\frac{\partial L_{1} R_{1} / M}{\partial A}=-4(\bar{L} / 2 M) f^{\prime \prime}(\bar{L} / 2) \frac{\partial L_{1}}{\partial A}=\frac{\bar{L}}{3 M}>0
$$

In addition, differentiating of $\left(\bar{L}-L_{1}\right) R_{2}$ yields

$$
\frac{\partial\left(\bar{L}-L_{1}\right) R_{2} / M}{\partial A}=-\frac{\bar{L}}{3 M}<0
$$

Therefore, regardless of whether the amenity affects consumption or production, total rent extraction, and thus the public-sector wage, is higher in region 1 than in region 2 . With a 
stronger amenity tending to pull private-sector workers toward region 1, public-sector workers are thus able to extract more rent as $A$ increases. Because $L_{1}$ is large for any given $R_{1}$ when $A$ is large, public-sector workers enjoy a bigger population base for rent extraction, allowing them to better tolerate the population loss resulting from this behavior and thus to pursue it more aggressively.

Note that when the amenity has a consumption component, the increase in $A$ yields also yields nonpecuniary amenity benefits to region 1's public-sector workers, compounding their gain from a higher wage. Since public-sector workers are immobile, however, no migration force works to offset these benefits (region 2's public-sector workers cannot relocate).

A key final question concerns how the public-sector wage gap between the high- and lowamenity regions compares to the private-sector gap. Since the public-sector wage rises (falls) at the same rate in region 1 (2) as $A$ increases, the regional public-sector wage gap is proportional to twice the relevant derivative from (16), or $2 \bar{L} / 3 M$. Since the private-sector wage changes at a rate equal to $\alpha-1 / 6$ in region 1 while rising at a rate of $1 / 6$ in region 2 , the regional wage gap is proportional to $(\alpha-1 / 6)-1 / 6$, or $\alpha-1 / 3$, which can take either sign. Thus, the regional public-sector wage gap exceeds the private-sector wage gap when

$$
\frac{2 \bar{L}}{3 M}>\alpha-\frac{1}{3}
$$

When $\alpha$ is small, the right-hand side of (13) is negative, indicating that the private-sector wage is lower in region 1 than in region 2, an outcome that makes the regional gap negative and thus lower than the positive public-sector wage gap. But when $\alpha>1 / 3$, the private-sector gap is positive, making the relationship between the public and private gaps not immediately clear. But since the right-hand side of (18) is less than 1 , the inequality will be satisfied when $2 \bar{L} / 3 M>1$ or when $\bar{L}>(3 / 2) M=(3 / 4)(2 M)$. The latter inequality states that the total private work force in both regions $(\bar{L})$ is larger than $3 / 4$ of the total public work force, which equals $2 M{ }^{16}$ Since the private work force is in reality much larger than the public work force, this condition is realistic, and the regional public-sector wage gap exceeds the private-sector gap. This conclusion and (16) yield the main empirical hypotheses generated by the model: 
Proposition 1. Under the maintained assumptions, amenities raise the absolute level of public-sector wages while also raising these wages relative to private-sector wages. In other words, the public-sector wage gap between the high-and low-amenity regions is always positive, and it exceeds the private-sector wage gap, which can be either positive or negative depending on the nature of the amenity.

In the case of a pure consumption amenity, the differential effect of the amenity on publicand private-sector wages is transparent. The in-migration generated by an increase in the amenity depresses labor's marginal product and thus the private-sector wage, while the population gain is exploited by public-sector workers to raise total rent extraction and thus their individual wage. With a pure production amenity, the rise in the private-sector wage compounds the benefit from in-migration, expanding the scope of possible rent extraction and leading to a public-sector wage increase that exceeds the private increase.

Note that this latter outcome would be reversed if the public work force were much larger than the private-sector work force, so that (18) is not satisfied. With results of rent extraction needing to be shared across many public-sector workers, the increase in the individual wage would then be smaller, making the public-sector wage gap between high and low-amenity regions less than the private-sector gap.

\subsection{Adding housing consumption}

The previous results are mostly unaffected under several modifications of the model. First, the assumption that public-sector workers do not consume the public good can be relaxed without affecting any of the previous results. The appendix demonstrates this conclusion by allowing the public good to enter the utility functions of both types of workers while requiring public-sector workers to pay taxes.

The analysis so far suppresses housing consumption and housing prices, which play a key role in Roback-style models. However, these elements can also be added to the current framework without substantially affecting any of the previous results, provided the addition is done in a certain way. Specifically, private-sector workers are assumed to consume land (interpreted as housing), while public workers are not consumers of land and firms do not require a land input, using only labor. Making the latter two groups of agents land-users would require major changes to the model, with uncertain effects on the results. 
Let $q_{1}$ and $q_{2}$ denote individual land consumption by private workers in the two regions, and let the (additively separable) utility from housing consumption be $s\left(q_{i}\right)$. Letting $p_{1}$ denote the land price in region 1 , the utility expression on the left-hand side of (3) is then augmented by the terms $s\left(q_{1}\right)-p_{1} q_{1}$. Since the first-order condition for choice of $q_{1}$ is $s^{\prime}\left(q_{1}\right)=p_{1}$, these new terms can be replaced by $s\left(q_{1}\right)-s^{\prime}\left(q_{1}\right) q_{1}$. The analogous expression $s\left(q_{2}\right)-s^{\prime}\left(q_{2}\right) q_{2}$ appears on the right-hand side of (3).

With two new unknowns, $q_{1}$ and $q_{2}$, appearing in the model, additional equilibrium conditions are needed, and these conditions come from market-clearing requirements. Letting the residential land area in each region be fixed and normalized to one, the market-clearing conditions are $L_{1} q_{1}=1$ and $L_{2} q_{2}=1$. For region $1, q_{1}$ is then given by $1 / L_{1}$, so that the new terms on the left-hand side of (3) become

$$
s\left(1 / L_{1}\right)-s^{\prime}\left(1 / L_{1}\right) / L_{1} \equiv h\left(L_{1}\right)
$$

where $h^{\prime}\left(L_{1}\right)=s^{\prime \prime}\left(1 / L_{1}\right) L_{1}^{-3}<0$. Let $g\left(L_{1}\right) \equiv f^{\prime}\left(L_{1}\right)+h\left(L_{1}\right)$, with $g^{\prime}\left(L_{1}\right)=f^{\prime \prime}\left(L_{1}\right)+h^{\prime}\left(L_{1}\right)<$ 0 . Then, the equal-utility condition in (3) can be written as

$$
g\left(L_{1}\right)-z_{1}-R_{1}+A+v\left(z_{1}\right)=g\left(\bar{L}-L_{1}\right)-z_{2}-R_{2}+v\left(z_{2}\right)
$$

Since $g(\cdot)$ takes the place of $f^{\prime}(\cdot)$, and since both functions are decreasing in $L_{1}$, the analysis leading to the key derivatives (11) and (12) is unaffected, with $g^{\prime}$ replacing $f^{\prime \prime}$ in (12). In addition, the impact of the amenity on public-sector rent is unaffected, with (16) and (17) continuing to hold.

Although the calculation of $A$ 's impact on the private-sector wage is altered, the previous conclusion on the effect of amenities on the wage gap is unchanged. With (12) using $g^{\prime}$ instead of $f^{\prime \prime}$, the wage derivative is

$$
f^{\prime \prime} \frac{\partial L_{1}}{\partial A}+\alpha=f^{\prime \prime}\left(-\frac{1}{6 g^{\prime}}\right)+\alpha=\alpha-\frac{\lambda}{6},
$$


where $\lambda=f^{\prime \prime} / g^{\prime}=f^{\prime \prime} /\left(f^{\prime \prime}+h^{\prime}\right)<1$ (the functions in this expression are evaluated at $\left.\bar{L} / 2\right)$. Thus, the private-sector wage once again rises with the amenity level unless the consumption component represents a large share of the total amenity effect (with $\alpha<\lambda / 6$ ). The regional public-sector wage gap is again larger than the private-sector wage gap (which equals $\alpha-\lambda / 3$ ), assuming that the previous condition on worker populations is satisfied. ${ }^{17}$ Proposition 1 thus continues to hold.

This modified model also generates predictions about land prices. Since $\partial L_{1} / \partial A>0$ and $s^{\prime \prime}<0$, it follows that region 1's land price, given by $p_{1}=s^{\prime}\left(1 / L_{1}\right)$ is increasing in $A$, with region 2's price decreasing in $A$. Thus, regardless of the nature of the amenity, land prices are higher in region 1 than in region 2. This prediction, as well as those above, might be modified in model that incorporates land consumption in a different fashion. ${ }^{18}$ The model can also generate a connection between rent-seeking and land prices like that explored Gyourko and Tracy $(1989 \mathrm{~b}, \mathrm{c})$, although the current focus is different. ${ }^{19}$

A final point that is useful in the empirical work involves the comparison between the amenity's private-sector wage impact with and without housing consumption. As seen above, when housing consumption is absent, the regional wage gap is proportional to $\alpha-1 / 3$. In the presence of housing, the gap is $\alpha-\lambda / 3$, a larger quantity given $\lambda<1$. The reason for this relationship is that the increase in housing prices chokes off migration sooner in response to an amenity gap, keeping wages farther apart.

A key implication of these two formulas is that, if the amenity's consumption component is large ( $\alpha$ is small), the regional wage gap could be positive in the presence of housing $(\alpha-\lambda / 3>$ $0)$ but negative in housing's absence $(\alpha-1 / 3<0) .{ }^{20}$ Empirically, housing can be "removed" from the model by holding housing prices constant in a regression that compares wages in high- and low-amenity regions. The previous conclusion then says that, when the amenity has a large consumption component, the private-sector wage comparison could show a negative gap between high and low-amenity regions controlling for housing-price gaps while showing a positive gap when prices are not controlled for. Such a contrast would indicate that the amenity has an important consumption component along with its production effect. 


\subsection{Comparison to the Roback model}

The present model differs from the standard Roback model in several ways. In addition to the presence of rent-seeking public-sector workers, firms in the model do not use land, in contrast to the standard assumption of a land input, and the usual profit-equalization condition for firms is absent. Despite these differences, the predicted amenity effects on private-sector wages and house prices are identical to those in the Roback framework. In particular, the amenity lowers the private-sector wage in the consumption-amenity case and raises it in the production amenity case, with the effect ambiguous in the case of a composite amenity. In addition, regardless of the nature of the amenity, house prices are higher in the high-amenity region than in the low-amenity region.

The new implications of the model concern the public-sector wage. This wage is higher in the high-amenity region regardless of the nature of the amenity. In addition, under reasonable conditions on the relative size of the public and private sectors, and regardless of the nature of the amenity, the public-sector wage gap between high- and low-amenity regions is larger than the private-sector wage gap (which can be negative). These predictions are tested in the remainder of the paper. ${ }^{21}$

\section{Data}

The predictions of the model developed in the previous section are tested using data from the Current Population Survey (CPS) and other sources. The basic labor market data come from the Outgoing Rotation Group (ORG) files of the CPS, for the years 1994-2005. The beginning year is the first year after the redesign of the CPS, and we extend the data set only through 2005 because some of the other data items are measured in 2000 or earlier. We begin with the standard ingredients of wage equations, for a sample with the following restrictions: workers aged 18-64 earning wages or salaries (the self-employed and those working without pay are excluded). The full set of variables extracted from the CPS and used in the regressions is provided in the notes to the tables that follow. The dependent variable is the log of the hourly wage either reported by hourly workers or constructed for non-hourly workers. The straight wage is used, with some exclusions of obvious outliers. 
A key characteristic of workers is their classification as either private or public. Within the public sector, we distinguish between state, local and federal workers, and most of our analyses focus on how amenities shift wage differentials for public-sector state and local workers. We also explore the determinants of public-sector wage differentials for unionized public-sector workers, based on union membership as reported in the CPS.

Some of our analyses also focus more narrowly on public-sector workers who are kindergarten, elementary, or secondary school teachers, or alternatively corrections officers, occupations that are highly concentrated in the public sector and constitute large shares of publicsector employment. ${ }^{22}$ These classifications were made as consistent as possible across years, given a change in occupational coding between 2002 and 2003. ${ }^{23}$ Moreover, the estimated wage regressions include year dummy variables, so that any effects of changes in the composition of the occupations that affect wage levels are accounted for in the analysis.

We analyze the relationships between public-sector wages and four amenity variables measuring mild weather, dry weather, proximity to navigable water, and population density. The analysis is done at the state level. The model developed in the previous section could also operate at a more local level, and some of our amenity variables can of course vary within the larger states. But there are two problems with a local analysis. First, the physical amenities we study do not really differ across small areas. Second, even if they did, or even if we used different kinds of amenities with sharp local boundaries - such as school district quality - we might expect public-sector workers to sort across areas based on quality. For example, a highquality school district would likely attract better teachers who end up earning more, leading to spurious evidence that the school-quality amenity leads to high public-sector pay. Sorting of public-sector workers across states seems far less likely to be a concern, given relatively low mobility across states. ${ }^{24}$

The four amenity variables we use were chosen and defined prior to doing any of the analysis, based on our reading of key amenity variables at the state level from the existing urban and regional economics literature. We did not analyze any evidence for other amenities, and report the full evidence for each of these four amenities. Thus, there was no selection of results based on which amenities fit the models predictions. 
Mild is the negative of the sum of the absolute values of the differences between monthly average temperature and 20 degrees Celsius, summed over January, April, July, and October. Dry is the negative of the average monthly precipitation for those four months, in centimeters. The Mild and Dry variables are from Mendelsohn et al. (1994), and both are county-weighted state averages, using 2006 Census population estimates as weights. Proximity is the negative of the average distance from the state's county centroids, weighted by county population, to the nearest coast, Great Lake, or major river (Rappaport and Sachs, 2003). For each of these variables, a higher (less negative) value is "better," indicating less deviation from mild temperatures, less rain, and a shorter distance to navigable water. Density is the tract-weighted population density (per square mile) in the state, based on 1990 Census data (Glaeser and Kahn, 2004). Note that this variable differs from a simple density measure for a state because it is tract-weighted, with the goal of measuring density where people in a state live. As a result, the density measure is much higher than average tract density. Finally, we also make use of estimated state housing price premia. These price measures are computed from 2000 Census data (5 percent sample), as the state dummy variables in a hedonic regression for house prices. The computational method is the same as in Albouy (2009), although applied at the state level. Costs are based on both owned and rented homes and include utility costs, and the regression controls for rental and condominium status, dwelling size, rooms, acreage, commercial use, kitchen and plumbing facilities, and age of building. ${ }^{25}$

Table 1 shows the distribution of the sample observations, which include 1.75 million private and public-sector workers. Almost 14 percent of the observations are for public state or local workers, with almost 3 percent being federal. Unionized workers represent nearly 16 percent of the sample, and unionized state and local workers about 7 percent of the sample.

Descriptive statistics for the amenity variables are shown in Table 2. Note that North Dakota's temperatures are the least mild, while Florida's are the mildest. Louisiana is the least dry state while Nevada is the driest. Tiny coastal Delaware has the best water access, while New Mexico is the state most remote from bodies of water. New York is the densest state, while Arkansas is the least dense. 


\section{Empirical Findings}

The regression model takes the following form:

$$
\ln \left(w_{i s}\right)=\alpha+X_{i s} \beta+\gamma P S_{i s}+\sum_{k} \delta_{k} A_{s}^{k}+\sum_{k} \theta_{k} P S_{i s} A_{s}^{k}+\epsilon_{i s}
$$

where $w_{i s}$ is the wage for worker $i$ in state $s, X_{i s}$ is a vector of characteristics for that worker intended to control for productivity differences, $P S_{i s}$ is a dummy variable indicating whether the individual works in the public sector, and $A_{s}^{k}$ is the level of amenity $k$ in state $s$, with $k=1,2,3,4 .^{26}$ The hypotheses to be tested are: $\theta_{k}>0$, indicating that amenities raise public-sector wages relative to private-sector wages; and $\delta_{k}+\theta_{k}>0$, indicating that amenities raise the absolute level of public-sector wages. Note that the sign of $\delta_{k}$ (indicating the effect of an amenity on private-sector wages) could be positive or negative depending on the nature of the amenity. The observations in (22) actually come from multiple years, but this fact is suppressed for simplicity in writing the equation since the main variables of interest (amenities) are time invariant. A complete equation would thus include time indices and year fixed effects. Because we estimate the model using individual-level data, but the amenities vary only by state, we cluster the standard errors at the state level. Thus, although the microdata yields a huge sample, the effective number of observations is of course much smaller.

Note that rent extraction by public-sector workers means, literally, that they earn more than they otherwise would doing the same work in the private sector. We cannot directly observe whether this difference exists. However, labor economists typically use log wage regressions to detect wage differences net of productivity differences; examples include using wage regressions to estimate the effects of unions or discrimination on wages. The challenge is perhaps more difficult in estimating public-sector wage differentials, because work conditions may differ across sectors. Moreover, structural approaches to estimating productivity and pay differences (e.g., Hellerstein and Neumark, 1999) are likely to be inapplicable to the question at hand because of the difficulty of defining output for the public sector. Thus, our test involves estimating the relationship between amenities and the relative pay of public-sector workers, rather than a more explicit attempt to ask whether high amenities are associated with above-marginal-product wages. 


\subsection{Benchmark regressions lacking a public-private distinction}

As a benchmark, the first empirical specification (shown in Table 3) suppresses the distinction between the effects of amenities on wages of private- and public-sector workers, regressing the log of the wage on the amenity variables along with the large set of non-amenity controls (worker characteristics, and year fixed effects), whose coefficients are not reported. The first four columns show regressions containing just a single amenity measure, while the regression in column 5 contains all four measures. When included singly, Dry and Proximity have significantly positive coefficients, while the coefficients of Mild and Density are insignificant. When all four variables appear together, Mild's coefficient remains insignificant while the remaining amenity coefficients are all significantly positive.

With the public-worker share in the sample being small, the results in Table 3 are presumably driven mainly by the private-worker observations. Since the analysis in section 2 shows that a positive private-sector wage effect requires an amenity to have a production component, the positive coefficients for Dry, Proximity and Density evidently indicate that each of these amenities increases worker productivity in the private sector. Given the substantial evidence on agglomeration economies (see Rosenthal and Strange, 2004), the positive wage effect of density comes as no surprise. Less expected are the implied productivity benefits of a dry climate and water access.

As explained in section 2.3, if housing prices are held constant, then the wage impact of the amenity's production component is attentuated, providing a better chance for the negative influence of the consumption component to manifest itself. To investigate this possibility, column 6 of Table 3 adds the state housing-price premium for 2000 to the regression. The housing-price coefficient is itself positive and significant, indicating that wages are higher in states with expensive housing. With housing prices included, the coefficients of Dry and Proximity lose significance (the point estimates are negative), while the coefficients of Mild and Density become significantly negative. These negative relationships, as well as the sign changes for the insignificant coefficients, are what we would expect if each amenity has an important consumption component (with high density being favorable). Therefore, the results suggest that the four amenity variables contain both production and consumption components, 
with the production effect tending to dominate (yielding the positive coefficients in column 5).

The theoretical analysis showed that, regardless of the nature of the amenity, house prices should be higher in high- than in low-amenity regions. Table 4 tests this prediction by regressing the state housing-price premium on the amenity variables. As can be seen in column 5 , all the amenity coefficients are significantly positive, as predicted.

Before turning to the regressions that distinguish between private and public-sector workers, it is useful to sketch the connection between the results presented so far and the standard empirical implementation of the Roback (1982) model, as seen in Blomquist, Berger and Hoehn (1988). In the standard implementation, wage and house-price regressions like those in column (5) of Tables 3 and 4 are estimated, and the results are then merged to generate estimates of amenity consumption benefits, following guidance from the theory. For positive wage impacts like those in column (5) of Table 3 to emerge, amenity production effects must dominate consumption effects, just as in the present framework.

The previous literature also contains an analog to the regression in column 6 of Table 3. In particular, Henderson (1982) shows theoretically that if a house-price measure is included as a covariate in a Roback-style wage regression, then the resulting amenity coefficients directly measure the consumption benefits of amenities. He carries out such an estimation, generating plausible numerical values. By constrast, under the present model, a regression that controls for house prices does not yield a direct measure of consumption benefits. But the regression gives these benefits a better chance to show their existence by generating negative wage coefficients, as explained in section 2.3.

\subsection{Main results}

To test the main prediction of the model, as embodied in Proposition 1, public and privatesector workers must be distinguished. Accordingly, the regressions in columns 1-6 of Table 5 include a dummy variable identifying public state or local workers, and they also include interactions of this variable with the amenity measures. Note that the dummy coefficient reveals the difference in the levels of public- and private-sector wages, while the interactions show the difference in the wage impact of amenities between public- and private-sector workers.

Before considering these results, it should be noted that we face a limitation in estimating 
the effects of amenities on wages. Because these amenities are time-invariant, we cannot distinguish between actual effects of the amenities on wages and correlations between these amenities and other unmeasured state-specific factors that affect wages. However, in our main analyses described in this section, we are interested in the interactions between these amenities and public-sector employment. Thus, even if unmeasured state-specific factors influence wages, as long as they do not affect the difference between wages for otherwise similar private- and public-sector workers, these factors will not affect our results. Put equivalently, we can identify how local amenities affect public-sector wage differentials in the face of unmeasured statespecific influences on overall wage levels, even if we cannot identify the main effects of amenities. That is, the public-sector/amenity interactions are still identified if we include fixed state effects in the regressions. In some of the specifications reported below, we control for other statespecific factors, including some that may affect the public-sector wage differentials that we estimate. In addition, we show that the estimates of the public-sector/amenity interactions are robust to the inclusion of fixed state effects.

The (uninteracted) amenity level coefficients in Table 5, which show the amenity impact on private-sector wages, follow the same pattern as in Table 3, being significantly positive for Dry, Proximity and Density in the regression in column 5 containing all the amenities. In addition, the public-sector wage dummy is negative and significant, indicating that wages for state or local public workers are about 5 percent less than private-sector wages, conditional on all the covariates.

Turning to the interaction coefficients, the Proximity and Density coefficients are significantly positive in the single-amenity regressions (columns 1-4), and both these coefficients as well as the Mild interaction coefficient are significantly positive in the regression in column 5 containing all of the amenities. The null hypothesis that all the interaction coefficients are zero can also be rejected at a high confidence level. These results provide strong confirmation of the model's predictions by showing that public-sector wages rise even more than private-sector wages in the presence of amenities. Note also that, with both the amenity level and interaction coefficients being positive, the results also indicate that public-sector wages are high in absolute terms in high-amenity regions, matching the model's prediction. The bottom panel 
of Table 5 shows the sum of the level and interaction coefficients, with three out of four being significantly positive.

As seen in column 6, controlling for housing prices once again reverses the signs of the amenity impacts on private-sector wages, with all four point estimates negative and the Mild and Density coefficients significant. However, the interaction coefficients remain positive, again indicating that amenities raise public wages relative to private-sector wages when housing prices are held constant. Since the theory predicts that public-sector wages should rise in an absolute sense with amenities regardless of whether housing is present in the model, the sum of the amenity level and interaction coefficients should then be positive regardless of whether or not the regression controls for house prices. The bottom panel shows that this condition is met for Proximity and Density, for which the summed coefficients are significantly positive.

Column 7 drops nonunionized public-sector workers from the sample, so that comparisons are between unionized state or local public workers and private-sector workers (the sample size falls to 1.6 million). The results are qualitatively similar to those in column (5). The amenity level coefficients have the same pattern of signs and significance, while three of the interaction coefficients are again positive and significant (Mild and Dry swap significance). Note that the public-sector wage discount grows to 7 percent, evidently indicating that unionized workers are in lower-paying public job categories. Column 8 shows that controlling for housing prices leads to results very similar to those in column 6. Most important, perhaps, is the finding that the estimated public-sector wage premiums associated with amenities are larger for three out of the four amenities (and triple in size for Dry and Proximity), consistent with unions being able to extract more rents. If the comparison is instead between nonunionized publicsector workers and private workers, the wage premiums associated with amenities are smaller than those reported in columns 5 and 6 (but still always positive, and significant for all of the amenities except Dry in the specification with the housing-price premium included; results available on request).

A potential objection to Density as an amenity is that it can reflect other influences as well. First, unlike the other amenity variables, Density is potentially endogenous. However, although high wage levels overall may attract residents, our concern is with the estimated 
wage gap between public- and private-sector workers. Taking the model seriously, if anything a high relative public-sector wage should imply less population in a state, conditional on the amenities, implying that, if anything, endogeneity should bias the estimated effect of Density on the public-sector versus private-sector wage gap downward - making our evidence of a positive effect of density on this gap even stronger. Second, high density can correspond to high urbanization, and working conditions in urban areas may be worse - think of teachers in poor urban districts - necessitating higher wages in the public-sector specifically. One response to this concern is to note that our qualitative results do not depend on the evidence for Density. In particular, the estimates for other amenities also provide evidence consistent with the model's predictions. Also, although not reported in the table, the three interactions excluding the one for Density were also jointly significant-in this case, and in all other cases covered in the specifications that follow. The results therefore are not driven by the estimated interaction for Density. A second response is that when we look at estimates for two particularly important groups of public-sector workers - teachers and corrections officers - we add control variables that should to some extent proxy for these working conditions, and the results are unaffected.

We next explore the robustness or sensitivity of these results along a number of dimensions. First, it is possible that public-sector workers differ from other workers in observable characteristics, and that it is these other characteristics that - for some reason-are associated with wage differentials that vary with amenities. To address this question, Table 6 reports estimates for various subsets of the sample, including urban vs. non-urban residents, moreand less-educated workers, and workers in different race or ethnic groups. The estimates are reported for the specification from column (8) of Table 5, focusing on the unionized publicsector workers for whom the theoretical prediction as well as the evidence is stronger. As the table shows, the results are largely unchanged within each of these subgroups, although not surprisingly, the statistical significance of the estimates is sometimes a bit weaker. ${ }^{27}$

What do these estimates imply for actual public-sector vs. private-sector wage differentials? To provide some idea of what the magnitudes mean, consider (from Table 2) the implied difference in the public-sector wage differential for workers in the worst state compared to the best state for each amenity. For example, for Mild, the implied effect of being located in 
Florida instead of North Dakota is the difference in the amenity values in Table 2 multiplied by the corresponding public-sector/amenity interaction coefficient of 0.0012 , or a log differential of 0.055 (or approximately 5.5 percent). For Dry, Proximity, and Density, the corresponding magnitudes for the difference between the worst and best states are 2.5, 10.2, and 2.9 percent. Effects of these magnitudes are non-neglible and plausible. ${ }^{28}$

In Table 7, public-sector workers are limited to those employed at the state level, excluding local public workers. For local public-sector workers, the ability to extract rents may be weaker in smaller localities (Rose and Sonstelie, 2010), or the statewide amenity measures may not capture local amenities well. On the other hand, the local public-sector workers in large cities, who make up a large share of the public-sector workforce in the state, may be among the public-sector workers most able to extract rents. The results excluding these local workers, however, are very similar to those in Table 5. The amenity level and interaction coefficients are typically positive and significant in columns 5 and 7 , a conclusion that also applies to the sum of the coefficients. Several amenity-level coefficient signs switch to negative in columns 6 and 8 when housing prices are included, with interaction coefficients remaining positive. As in Table 5, for three out of the four amenities the associated public-sector wage premiums are usually larger when we focus exclusively on public-sector workers who are unionized (and weaker, although not reported in the table, when the focus is on nonunionized public-sector workers).

As noted earlier, our amenity variables are potentially correlated with other unobserved characteristics of states. Although these correlations can contaminate estimates of the effects of amenities on private-sector wages, they will not bias the estimated effects of the publicsector/amenity interactions, as long unobservables shift private- and public-sector wages similarly, which seems like a reasonable assumption. For example, if public goods are normal, and high-income people sort into high-amenity areas, then high-amenity areas may have higher levels or qualities of public goods. While this sorting could generate a link between amenities and public-sector pay, it need not imply that amenities are associated with higher public-sector pay relative to private-sector pay. To illustrate, Table 8 reports estimates that include state fixed effects. These fixed effects subsume the main effects of amenities, which vary only at 
the state level, but the public-sector/amenity interactions are still identified. Table 8 shows that the estimated effects of amenities on the gap between public- and private-sector wages are very robust to the inclusion of the state fixed effects, as the estimates are very similar to the corresponding estimates in Tables 5 and $7 .^{29}$

One potential state "effect" that could shift public-sector wages relative to private-sector wages, and hence still bias the estimated public-sector/amenity interactions, is the political composition of a state. In particular, if a more-Democratic state pays public-sector workers higher wages, and this same political composition does not lead to similarly higher privatesector wages, then our key estimated interactions would be biased if the amenities vary systematically across more- and less-Democratic states. To check for such bias, we added data on the Democratic vote share in the 1988 and 1992 presidential elections. ${ }^{30}$ Specifically, we added the vote share and the vote share interacted with the dummy variable for public-sector status. As Table 9 shows, the key results for the public-sector/amenity interactions are very similar to the previous ones in both magnitude and statistical significance; indeed in some cases the results get stronger. ${ }^{31}$ Only in one case - for the analysis looking at both union and nonunion workers incorporating the Clinton vote share (column (3), lower panel) - is there a notable weakening of the evidence. But for this specification, when the analysis is restricted to public-sector union workers, the evidence is much stronger. The conclusion is that our findings are robust to controlling for what is likely the most important alternative source of public-sector versus private-sector wage differentials across states.

\subsection{Results for teachers and corrections officers}

It is useful to test the model's predictions on even narrower classes of public-sector workers, specifically teachers and corrections officers. Table 10 shows distributional information for elementary and secondary school teachers. Three quarters of such teachers are public workers, with the rest being privately employed. Almost 10 percent of teachers self-report that they are state-employed, ${ }^{32}$ while about half of all teachers are union members, regardless of sector.

Table 11 shows the previous regression specifications with public-sector workers limited to state and local teachers. Only specifications with all of the amenity variables are reported. In column 1, three amenity level coefficients are positive, again indicating higher private-sector 
wages in high-amenity states. The teacher dummy coefficient shows that teachers earn 18 percent less than otherwise comparable nonteachers, while the coefficient for public workers (all of whom are teachers) shows that these individuals earn 10 percent more than other teachers. As in Table 5, three out of four amenity interaction coefficients are positive (Dry's effect is insignificant), showing that amenities raise public teacher salaries more than those of private-sector workers. In two cases, the sum of the amenity level and interaction coefficients is significantly positive, indicating higher absolute teacher wages in high-amenity states.

From column 2, the addition of the housing-price premium yields results that match previous findings, with all the amenity level coefficients turning negative (two are significant), while the interaction terms retain their previous positive sign and significance. Column 3 adds the student-teacher ratio interacted with the public-teacher dummy variable in order to control for the quality of the work environment, which may be related to public-sector wage differentials, either because the work environment affects wages or because the higher wages lead to a higher student-teacher ratio. ${ }^{33}$ Note that the inclusion of this variable interacted with public-sector employment addresses the issue raised earlier regarding other sources of statelevel variation in public-sector wage differentials. In this case, for example, student-teacher ratios may vary across states, and this variation, in turn, may be related to the wage premium for public-school teachers for reasons unrelated to local amenities. The interaction coefficient is insignificant, indicating no relationship between public-sector wage differentials (for teachers) and student-teacher ratios, and its inclusion has no effect on the main results regarding the public-sector/amenity interactions. Columns 4-6 of Table 11 restrict public-sector teachers to those that are unionized, and the results are largely unaffected.

Turning to the case of corrections officers, Table 12 gives distributional information. Among corrections officers (who staff prisons and jails), 95 percent are state or local employees, and more than half are union members. Table 13 shows regressions where state and local employees are limited to corrections officers, and the results closely match previous patterns, despite the much smaller number of public-sector workers for whom the results are identified. From column 1, corrections officers earn 10 percent more than otherwise comparable workers, while if they are public state or local employees, that premium is reduced to about 3 percent. The 
positive amenity level coefficients again show that amenities raise private-sector wages, while the positive interaction coefficients (three of which are again significant) indicate that the wages of corrections officers rise by more than those of private workers in the presence of amenities. The sum of the two coefficients is also significantly positive in three out of four cases.

Adding the housing-price premium generates now-familiar changes in the amenity impacts on private-sector wages, as shown in column 2. Column 3 includes a work-environment measure, equal to inmates per officer, interacted with the corrections-officer dummy. This measure controls for a potential source of across-state variation in public-sector wage differentials for this particular set of public-sector workers. Its impact (along with that of a level effect) is insignificant, and its inclusion does not affect the other results. Columns 4-6 restrict attention to unionized corrections officers, and the results are mostly unchanged, although the effects of amenities on the public-sector wage premium are generally stronger.

Finally, the regressions in Table 14 provide a falsification test by using federal rather than state or local workers to represent public-sector employees. With federal wages mostly uniform across the country, ${ }^{34}$ or in some cases reflecting local private-sector pay, public-sector wage differentials in federal employment should not show the same positive relationship to state amenities as the differentials for state and local workers. This prediction is confirmed by the results in column 1, where we never find a positive public-sector/amenity interaction

coefficient. ${ }^{35}$ Restricting attention to unionized federal workers (column 2) has little effect on the results. ${ }^{36}$

\section{Conclusion}

Non-competitive influences on public-sector pay have been long debated. On the one hand, the lack of a competitive market, the presence and continuing strength of public-sector labor unions, and the high level of political involvement of these unions all suggest that public-sector workers - particularly when unionized - can influence their pay and employment. On the other hand, public-sector pay (and employment) decisions are not made in a vacuum, as taxpayers can migrate away from locations in which public-sector goods and services are provided in an excessively costly fashion. 
The presence of local amenities, however, can grant public-sector workers a form of monopoly power that lets them extract more rents. People can only consume the beaches and sunshine of southern California, or benefit from the higher productivity of dense urban areas like Manhattan, by living nearby, and public-sector workers can therefore extract rents up to the point where those who pay the rents are induced to leave these high-amenity areas.

The data bear out this connection between amenities and rent-seeking behavior. When we estimate standard log wage regressions, we find that public-sector wage differentials are in fact larger in the presence of strong amenities, as are the absolute levels of public-sector wages. The results are the same whether we look at state and local workers overall or just state workers, and when we look at important subsets of these workers who receive a lot of attention in the debate over public-sector pay - teachers and prison guards. Furthermore, the relationship between public-sector wage differentials and amenities is stronger for unionized public-sector workers, consistent with their greater ability to extract rents through both organization and influence over the political process. The data also pass a falsification test, given that we find no evidence of a connection between wage differentials for federal workers and these same amenities.

Despite our compelling evidence, the paper by no means offers a "complete" theory of public-sector wage determination. Surely, institutional factors such as the cross-state variation in labor laws studied by Freeman and Valetta (1988) matter, as does the productivity of public-sector workers and the level of alternative wages they can earn in the private sector. Developing a fuller understanding of these various influences on public-sector wages can clarify the policy debate on public-sector pay, and may prove useful in considering possible reforms to reduce rent extraction by public-sector workers.

Finally, our empirical analysis is limited to state-level variation in local amenities and public-sector wage differentials. Although it may be hard to define the scope of local markets, and sorting of workers would be more problematic, richer data on local amenities and these wage differentials might permit additional tests of our hypothesis. In addition, in principle our analysis can be applied to differences in fringe benefits between the private and public sector, and studying the connection between benefits and amenities may be particularly informative 
in light of recent concerns over public-sector pensions.

Finally, the same considerations regarding rent extraction and amenities may apply to other workers who are not necessarily concentrated in the public sector but for whom pay is strongly influenced by government regulations, political power (in part through unionization), and other non-competitive forces. More generally, a similar story may apply to any group that attempts to use political influence to achieve goals that impose costs on other taxpayers. High levels of amenities may impede the mobility of taxpayers that would otherwise put the brakes on efforts to raid the public till in pursuit of rents or other objectives. 


\section{Appendix}

\section{Adding public-worker z consumption}

The preceding results are unaffected when public-sector workers consume the public good along with private-sector workers. Suppose that, instead of caring only about $x$, public workers value the public good and pay the same tax as private workers. This tax equals $z_{i}+R_{i}$, so that public workers are paying to cover their own rent extraction $\left(R_{i}\right.$ now denotes rent extraction per worker, public and private). Their income equals $w+\left(L_{i}+M\right) R_{i} / M$, where $w$ is some fixed base wage, and where the second term is rent per public worker (of which there are $M$ in each jurisdiction). This term equals the rent component of the tax $\left(R_{i}\right)$ times the total number of workers paying the tax $\left(L_{i}+M\right)$, divided by the number of public workers.

A public worker's budget constraint is then $x_{i}=w+\left(L_{i}+M\right) R_{i} / M-z_{i}-R_{i}=w+L_{i} R_{i} / M-$ $z_{i}$. Note that the portion of the tax covering rent extraction cancels the corresponding part of income, so that rent extraction continues to yield $L_{i} R_{i} / M$ per public worker. Assuming that public-sector workers share private-worker preferences, the public-sector workers in region 1 seek to maximize

$$
w+L_{1} R_{1} / M-z_{1}+v\left(z_{1}\right)
$$

subject to the migration constraint in (3). The choice variables are $z_{1}, R_{1}$, and $L_{1}$, with $z_{2}$ and $R_{2}$ viewed as fixed.

Letting $\mu$ denote the multiplier associated with the constraint, the first-order condition for choice of $z_{1}$ is $(1+\mu)\left[v^{\prime}\left(z_{1}\right)-1\right]=0$. Therefore, the condition $v^{\prime}\left(z_{1}\right)=1$ again emerges, so that $z_{1}=z^{*}$. But with $z_{1}$ fixed at this value, the remainder of the optimization problem is to maximize $L_{1} R_{1} / M$ subject to (3). But since this problem has already been solved via the previous analysis, the previous conclusions are unaffected. 
Figure 1: Plot of Public Sector vs. Private Sector Wage Differentials by State

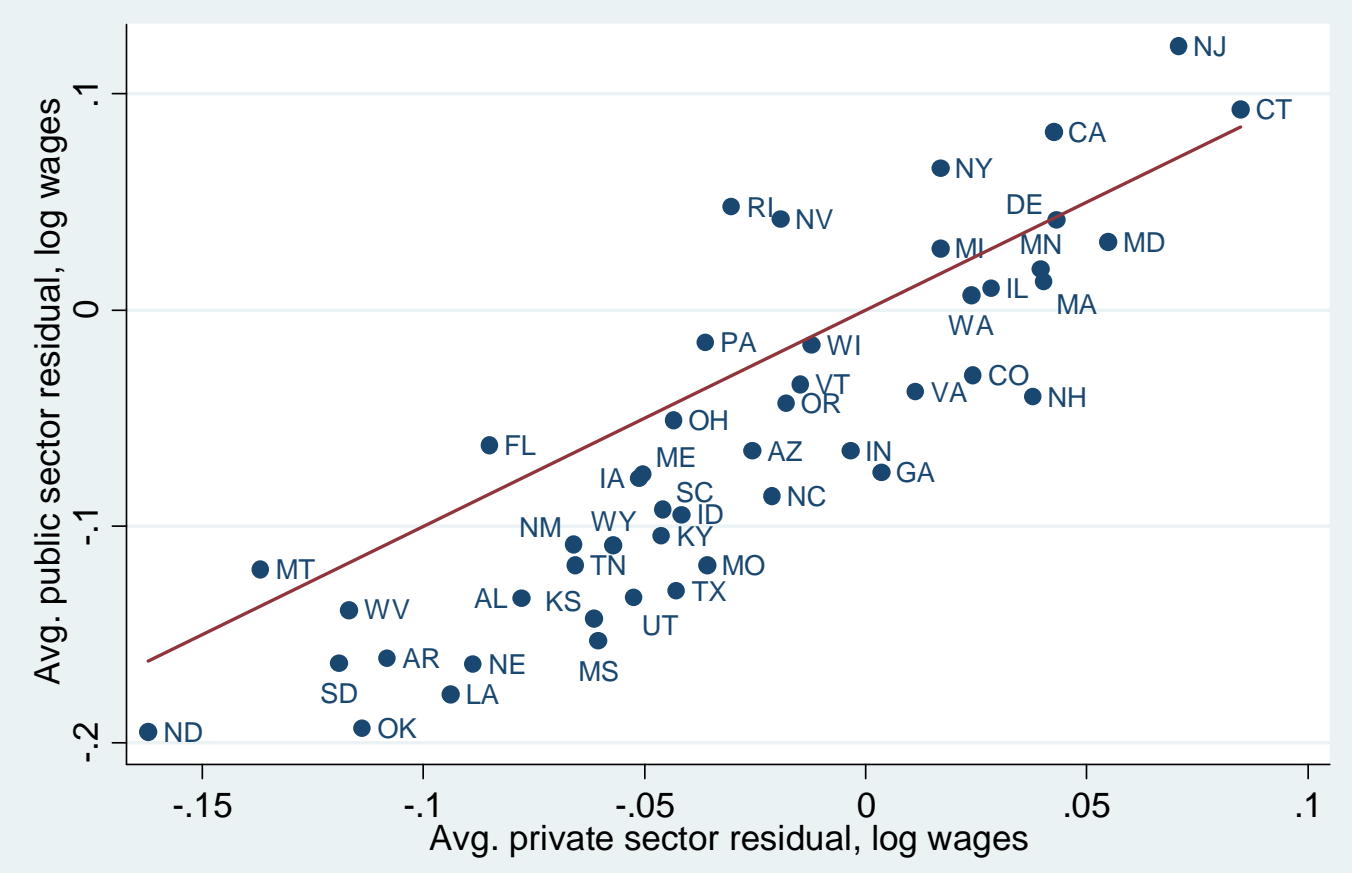

- Residuals

Slope $=1$

Notes: Plotted points are state averages of residuals from separate log wage regressions estimated for state or local public-sector workers and private-sector workers. Estimates are weighted, and include controls for education (16 categories), age and its square, union membership, sex, race, Hispanic ethnicity, marital status (7 categories), residence in a metro area, and year dummy variables.

Source: CPS ORG files, 1994-2005. 
Table 1: Descriptive Statistics on Distribution of Workers by Sector and Union Membership

\begin{tabular}{|l|c|}
\hline Public state or local & 0.136 \\
\hline Public state only & 0.042 \\
\hline Public federal & 0.026 \\
\hline Union member & 0.156 \\
\hline $\begin{array}{l}\text { Union member and public state or } \\
\text { local }\end{array}$ & 0.065 \\
\hline $\begin{array}{l}\text { Union member and public state } \\
\text { only }\end{array}$ & 0.015 \\
\hline Union member and public federal & 0.010 \\
\hline
\end{tabular}

Notes: The sample size is 1,746,644, covering the 48 continental states. Estimates are weighted.

Source: CPS ORG files, 1994-2005. 
Table 2: Descriptive Statistics on Amenities by State

\begin{tabular}{|l|c|c|c|c|c|c|}
\hline & Mean & Std. dev. & Min. (state) & 5 worst states & Max. (state) & 5 best states \\
\hline Mild & -40.1 & 11.4 & -62.7 (ND) & ND,MN,SD,ME,VT & -17.1 (FL) & FL,LA,CA,TX,MS \\
\hline Dry & -7.5 & 2.9 & -12.1 (LA) & LA,MS,WA,AL,GA & -1.7 (NV) & NV,AZ,NM,WY,ID \\
\hline Proximity (1,000s) & -0.190 & 0.241 & -0.96 (NM) & NM,UT,WY,CO,MT & -0.010 (DE) & DE,RI,NJ,NY,FL \\
\hline Density (10,000s) & 0.322 & 0.403 & 0.075 (AR) & AR,MS,WV,SD,VT & 2.74 (NY) & NY,CA,NJ,IL,MA \\
\hline
\end{tabular}

Notes and sources: The data cover the 48 continental states. Definitions of variables (and sources) are as follows. "Mild" is the negative of the sum of the absolute values of the difference between monthly average temperature and 20 degrees Celsius, summed over January, April, July, and October. "Dry" is the negative of the average monthly precipitation for those four months, in centimeters. Both are county-weighted state averages, using 2006 Census population estimates to weight. "Proximity" is the negative of the average distance from the state's county centroids, weighted by county population, to the nearest coast, Great Lake, or major river. "Density" is the tract-weighted population density (per square mile) in the state, based on 1990 Census data (Glaeser and Kahn, 2004). Note that this is different from a simple density measure for a state, because it is tract-weighted. The idea is to measure density where people in a state live. As a result, this density measure is much higher than average density measures. For the 5 worst (best) states, the states are listed in increasing (decreasing) order. 
Table 3: Standard Wage Regressions Incorporating Amenity Variables

\begin{tabular}{|l|c|c|c|c|c|c|}
\hline & $(1)$ & $(2)$ & $(3)$ & $(4)$ & $(5)$ & $(6)$ \\
\hline Mild & 0.0002 & & & & -0.0002 & -0.0013 \\
& $(0.0012)$ & & & & $(0.0005)$ & $(0.0004)^{* * *}$ \\
\hline Dry & & 0.010 & & & 0.012 & -0.0004 \\
& & $(0.003)^{* * *}$ & & & $(0.002)^{* * *}$ & $(0.002)$ \\
\hline Proximity & & & 0.109 & & 0.138 & -0.006 \\
& & & $(0.063)^{*}$ & & $(0.039)^{* * *}$ & $(0.025)$ \\
\hline Density & & & & 0.019 & 0.012 & -0.015 \\
& & & & $(0.013)$ & $(0.006)^{* *}$ & $(0.004)^{* * *}$ \\
\hline State \\
housing & & & & & & 0.023 \\
price & & & & & & $(0.003)^{* * *}$ \\
premium & & & & & & \\
(\$1,000s) & & & & & & \\
\hline
\end{tabular}

Notes: The sample size is 1,746,644. Estimates are weighted. See notes to Table 4 for definition of state housing price premia. The regressions include controls for education (16 categories), age and its square, union membership, public state or local employment, sex, race, Hispanic ethnicity, marital status (7 categories), residence in a metro area, and year dummy variables. Standard errors are clustered at the state level, and are reported in parentheses. ${ }^{* * *},{ }^{* *}$, and ${ }^{*}$ indicates that the estimate is statistically significant at the 1-, 5-, or 10-percent level, based on a $t$-distribution with degrees of freedom equal to the number of states (clusters) minus one.

Source: CPS ORG files, 1994-2005. 
Table 4: Regressions of State Housing Price Premium (\$1,000s) on Amenity Variables

\begin{tabular}{|l|c|c|c|c|c|}
\hline & $(1)$ & $(2)$ & $(3)$ & $(4)$ & $(5)$ \\
\hline Mild & 0.028 & & & & 0.038 \\
& $(0.025)$ & & & & $(0.018)^{* *}$ \\
\hline Dry & & 0.297 & & & 0.382 \\
& & $(0.109)^{* * *}$ & & & $(0.096)^{* * *}$ \\
\hline Proximity & & & 2.330 & & $\begin{array}{c}3.694 \\
(1.577)^{* *}\end{array}$ \\
\hline Density & & & $(1.839)$ & & 1.750 \\
& & & & $(0.402)^{* * *}$ & $(0.361)^{* * *}$ \\
\hline
\end{tabular}

Notes: The sample size is 48. Estimates are weighted by the same weights used in the wage regressions (the CPS earnings weights), which provides approximate weighting by population size while weighting observations in different states the same as in the wage regressions. State housing price premia are computed from 2000 Census data (5 percent sample), as the state dummy variables in a hedonic regression for house prices. The computational method is the same as in Albouy (2009), although applied at the state level. Costs are based on both owned and rented homes and include utility costs, and the regression controls for rental and condominium status, dwelling size, rooms, acreage, commercial use, kitchen and plumbing facilities, and age of building. Sources: CPS ORG files, 1994-2005; 2000 Census 5\% sample. 
Table 5: Wage Regressions with Public Sector-Amenity Interactions, for Public State or Local Workers

\begin{tabular}{|c|c|c|c|c|c|c|c|c|}
\hline & \multicolumn{6}{|c|}{ Union and nonunion public-sector workers vs. all workers } & \multicolumn{2}{|c|}{$\begin{array}{l}\text { Only union public-sector } \\
\text { workers vs. all workers }\end{array}$} \\
\hline & (1) & (2) & (3) & (4) & (5) & (6) & (7) & (8) \\
\hline Mild & $\begin{array}{l}-0.0002 \\
(0.0012)\end{array}$ & & & & $\begin{array}{l}-0.0004 \\
(0.0005)\end{array}$ & $\begin{array}{l}-0.0014 \\
(0.0005)^{* * *}\end{array}$ & $\begin{array}{l}-0.0004 \\
(0.0005)\end{array}$ & $\begin{array}{l}-0.0014 \\
(0.0005)^{* * *}\end{array}$ \\
\hline Dry & & $\begin{array}{c}0.009 \\
(0.003)^{* * *}\end{array}$ & & & $\begin{array}{c}0.011 \\
(0.002)^{* * *}\end{array}$ & $\begin{array}{l}-0.0015 \\
(0.0023)\end{array}$ & $\begin{array}{c}0.011 \\
(0.002)^{* * * *}\end{array}$ & $\begin{array}{l}-0.0011 \\
(0.0024)\end{array}$ \\
\hline Proximity & & & $\begin{array}{c}0.089 \\
(0.061)\end{array}$ & & $\begin{array}{c}0.114 \\
(0.036)^{* * *}\end{array}$ & $\begin{array}{l}-0.030 \\
(0.029)\end{array}$ & $\begin{array}{c}0.118 \\
(0.037)^{* * *}\end{array}$ & $\begin{array}{l}-0.023 \\
(0.028)\end{array}$ \\
\hline Density & & & & $\begin{array}{c}0.021 \\
(0.013) \\
\end{array}$ & $\begin{array}{c}0.013 \\
(0.007)^{*}\end{array}$ & $\begin{array}{l}-0.015 \\
(0.004)^{* * *}\end{array}$ & $\begin{array}{c}0.014 \\
(0.007)^{* *}\end{array}$ & $\begin{array}{c}-0.014 \\
(0.005)^{* * *}\end{array}$ \\
\hline $\begin{array}{l}\text { Public state or } \\
\text { local }\end{array}$ & $\begin{array}{c}-0.047 \\
(0.010)^{* * *}\end{array}$ & $\begin{array}{c}-0.046 \\
(0.010)^{* * *}\end{array}$ & $\begin{array}{c}-0.044 \\
(0.007)^{* * *}\end{array}$ & $\begin{array}{c}-0.044 \\
(0.010)^{* * *}\end{array}$ & $\begin{array}{c}-0.042 \\
(0.007)^{* * *}\end{array}$ & $\begin{array}{c}-0.041 \\
(0.007)^{* * *}\end{array}$ & $\begin{array}{l}-0.058 \\
(0.012)^{* * *}\end{array}$ & $\begin{array}{c}-0.060 \\
(0.012)^{* * *}\end{array}$ \\
\hline $\begin{array}{l}\text { Housing price } \\
\text { premium } \\
(\$ 1,000 \mathrm{~s})\end{array}$ & & & & & & $\begin{array}{c}0.023 \\
(0.003)^{* * *}\end{array}$ & & $\begin{array}{c}0.022 \\
(0.003)^{* * *}\end{array}$ \\
\hline $\begin{array}{l}\text { Public state or } \\
\text { local } \times \text { mild }\end{array}$ & $\begin{array}{c}0.0005 \\
(0.0009)\end{array}$ & & & & $\begin{array}{c}0.0010 \\
(0.0006)\end{array}$ & $\begin{array}{c}0.0012 \\
(0.0006)^{*}\end{array}$ & $\begin{array}{c}0.0005 \\
(0.0006)\end{array}$ & $\begin{array}{c}0.0006 \\
(0.0007)\end{array}$ \\
\hline $\begin{array}{l}\text { Public state or } \\
\text { local } \times \text { dry }\end{array}$ & & $\begin{array}{c}0.0025 \\
(0.0042)\end{array}$ & & & $\begin{array}{c}0.0025 \\
(0.0026)\end{array}$ & $\begin{array}{c}0.0024 \\
(0.0024)\end{array}$ & $\begin{array}{c}0.0061 \\
(0.0035)^{*}\end{array}$ & $\begin{array}{c}0.0061 \\
(0.0038)\end{array}$ \\
\hline $\begin{array}{l}\text { Public state or } \\
\text { local } \times \\
\text { proximity }\end{array}$ & & & $\begin{array}{c}0.137 \\
(0.051)^{* * *}\end{array}$ & & $\begin{array}{c}0.104 \\
(0.049)^{* *}\end{array}$ & $\begin{array}{c}0.107 \\
(0.053)^{* *}\end{array}$ & $\begin{array}{c}0.324 \\
(0.097)^{* * *}\end{array}$ & $\begin{array}{c}0.310 \\
(0.097)^{* * *}\end{array}$ \\
\hline $\begin{array}{l}\text { Public state or } \\
\text { local } \times \\
\text { density }\end{array}$ & & & & $\begin{array}{c}0.033 \\
(0.009)^{* * *}\end{array}$ & $\begin{array}{l}0.030 \\
(0.004)^{* * *}\end{array}$ & $\begin{array}{l}0.029 \\
(0.004)^{* * *}\end{array}$ & $\begin{array}{c}0.035 \\
(0.007)^{* * *}\end{array}$ & $\begin{array}{c}0.038 \\
(0.007)^{* * *}\end{array}$ \\
\hline $\begin{array}{l}\text { Joint } \\
\text { significance } \\
\text { (p-value) }\end{array}$ & & & & & $<0.001$ & $<0.001$ & $<0.001$ & $<0.001$ \\
\hline $\begin{array}{l}\text { Mild + } \\
\text { interaction }\end{array}$ & $\begin{array}{c}0.0003 \\
(0.0018)\end{array}$ & & & & $\begin{array}{c}0.0006 \\
(0.0006) \\
\end{array}$ & $\begin{array}{l}-0.0003 \\
(0.0003)\end{array}$ & $\begin{array}{c}0.0001 \\
(0.0007)\end{array}$ & $\begin{array}{l}-0.0008 \\
(0.0004)^{*}\end{array}$ \\
\hline $\begin{array}{l}\text { Dry + } \\
\text { interaction }\end{array}$ & & $\begin{array}{c}0.0112 \\
(0.0060)^{*}\end{array}$ & & & $\begin{array}{c}0.0132 \\
(0.0026)^{* * *}\end{array}$ & $\begin{array}{c}0.0009 \\
(0.0024)\end{array}$ & $\begin{array}{c}0.0167 \\
(0.0043)^{* * *}\end{array}$ & $\begin{array}{c}0.0050 \\
(0.0045) \\
\end{array}$ \\
\hline $\begin{array}{l}\text { Proximity + } \\
\text { interaction }\end{array}$ & & & $\begin{array}{c}0.226 \\
(0.099)^{* *}\end{array}$ & & $\begin{array}{c}0.217 \\
(0.072)^{* * *}\end{array}$ & $\begin{array}{c}0.077 \\
(0.036)^{* *}\end{array}$ & $\begin{array}{c}0.441 \\
(0.121)^{* * *}\end{array}$ & $\begin{array}{c}0.287 \\
(0.081)^{* * *}\end{array}$ \\
\hline $\begin{array}{l}\text { Density + } \\
\text { interaction }\end{array}$ & & & & $\begin{array}{c}0.054 \\
(0.022)^{* *}\end{array}$ & $\begin{array}{c}0.043 \\
(0.010)^{* * *}\end{array}$ & $\begin{array}{c}0.014 \\
(0.006)^{* *}\end{array}$ & $\begin{array}{c}0.049 \\
(0.011)^{* * *}\end{array}$ & $\begin{array}{c}0.024 \\
(0.009)^{* * *}\end{array}$ \\
\hline $\mathrm{N}$ & $1,746,644$ & $1,746,644$ & $1,746,644$ & $1,746,644$ & $1,746,644$ & $1,746,644$ & $1,597,046$ & $1,597,046$ \\
\hline
\end{tabular}

Notes and source: See notes to Tables 3 and 4 . The amenity variables are demeaned (based on the same population weights used for the regression, and using the same sample), so that the main effects capture the effect at the sample means. The regressions include controls for education (16 categories), age and its square, sex, race, Hispanic ethnicity, marital status (7 categories), residence in a metro area, federal employment, year dummy variables, a dummy variable for union membership, and interactions between the union membership dummy variable and the amenities included in the specification. In columns 7 and 8 nonunionized public-sector workers are excluded. The "amenity + interaction" rows report the sum of the main amenity effect and its interaction with the public-sector worker variable. Given that the regressions also include union-amenity interactions, these sums should be interpreted as the differences within the union or nonunion sector (and only the union sector in columns 7 and 8), and do not reflect differences in unionization between the private and public sectors.

Sources: CPS ORG files, 1994-2005; 2000 Census 5\% sample. 
Table 6: Wage Regressions with Public Sector-Amenity Interactions, for Unionized Public State or Local Workers, Sensitivity Analyses

\begin{tabular}{|c|c|c|c|c|c|c|c|}
\hline & Urban & Non-urban & $\begin{array}{c}\text { Less than } \\
\text { bachelor's degree }\end{array}$ & $\begin{array}{c}\text { Bachelor's } \\
\text { degree }\end{array}$ & $\begin{array}{c}\text { Non-black, } \\
\text { non-Hispanic }\end{array}$ & Black & Hispanic \\
\hline & $(1)$ & $(2)$ & (3) & $(4)$ & $(5)$ & $(6)$ & $(7)$ \\
\hline Mild & $\begin{array}{c}-0.0015 \\
(0.0005)^{* * *}\end{array}$ & $\begin{array}{c}-0.0015 \\
(0.0004)^{* * *}\end{array}$ & $\begin{array}{l}-0.0015 \\
(0.0004)^{* * *}\end{array}$ & $\begin{array}{l}-0.0012 \\
(0.0009)\end{array}$ & $\begin{array}{l}-0.0011 \\
(0.0006)^{*}\end{array}$ & $\begin{array}{c}-0.0020 \\
(0.0004)^{* * *}\end{array}$ & $\begin{array}{c}-0.0033 \\
(0.0002)^{* * *}\end{array}$ \\
\hline Dry & $\begin{array}{c}0.0002 \\
(0.0024)\end{array}$ & $\begin{array}{l}-0.010 \\
(0.004)^{* * *}\end{array}$ & $\begin{array}{l}-0.002 \\
(0.002)\end{array}$ & $\begin{array}{c}0.001 \\
(0.004)\end{array}$ & $\begin{array}{l}-0.001 \\
(0.003)\end{array}$ & $\begin{array}{c}0.002 \\
(0.002)\end{array}$ & $\begin{array}{c}0.002 \\
(0.002)\end{array}$ \\
\hline Proximity & $\begin{array}{l}-0.023 \\
(0.034)\end{array}$ & $\begin{array}{l}-0.039 \\
(0.031)\end{array}$ & $\begin{array}{c}-0.037 \\
(0.021)^{*}\end{array}$ & $\begin{array}{c}0.017 \\
(0.056)\end{array}$ & $\begin{array}{l}-0.006 \\
(0.030)\end{array}$ & $\begin{array}{l}-0.048 \\
(0.055)\end{array}$ & $\begin{array}{c}0.034 \\
(0.035)\end{array}$ \\
\hline Density & $\begin{array}{l}-0.011 \\
(0.005)^{* *}\end{array}$ & $\begin{array}{c}-0.039 \\
(0.008)^{* * *}\end{array}$ & $\begin{array}{c}-0.021 \\
(0.003)^{* * *}\end{array}$ & $\begin{array}{c}0.001 \\
(0.007) \\
\end{array}$ & $\begin{array}{c}-0.016 \\
(0.005)^{* * *}\end{array}$ & $\begin{array}{l}-0.011 \\
(0.004)^{* *}\end{array}$ & $\begin{array}{c}-0.018 \\
(0.004)^{* * *}\end{array}$ \\
\hline $\begin{array}{l}\text { Public state or } \\
\text { local }\end{array}$ & $\begin{array}{c}-0.054 \\
(0.011)^{* * *}\end{array}$ & $\begin{array}{l}-0.086 \\
(0.020)^{* * *}\end{array}$ & $\begin{array}{c}-0.047 \\
(0.008)^{* * *}\end{array}$ & $\begin{array}{c}0.058 \\
(0.012)^{* * *}\end{array}$ & $\begin{array}{l}-0.076 \\
(0.012)^{* * *}\end{array}$ & $\begin{array}{c}0.018 \\
(0.011)\end{array}$ & $\begin{array}{c}0.024 \\
(0.019)\end{array}$ \\
\hline $\begin{array}{l}\text { Housing price } \\
\text { premium } \\
(\$ 1,000 \mathrm{~s})\end{array}$ & $\begin{array}{c}0.022 \\
(0.003)^{* * *}\end{array}$ & $\begin{array}{c}0.028 \\
(0.005)^{* * *}\end{array}$ & $\begin{array}{c}0.023 \\
(0.002)^{* * *}\end{array}$ & $\begin{array}{c}0.021 \\
(0.005)^{* * *}\end{array}$ & $\begin{array}{c}0.024 \\
(0.004)^{* * *}\end{array}$ & $\begin{array}{c}0.021 \\
(0.003)^{* * *}\end{array}$ & $\begin{array}{c}0.013 \\
(0.003)^{* * *}\end{array}$ \\
\hline $\begin{array}{l}\text { Public state or } \\
\text { local } \times \text { mild }\end{array}$ & $\begin{array}{c}0.0006 \\
(0.0006)\end{array}$ & $\begin{array}{l}-0.0010 \\
(0.0012)\end{array}$ & $\begin{array}{c}0.0003 \\
(0.0005)\end{array}$ & $\begin{array}{l}-0.0012 \\
(0.0010)\end{array}$ & $\begin{array}{c}0.0003 \\
(0.0006)\end{array}$ & $\begin{array}{l}-0.0002 \\
(0.0013)\end{array}$ & $\begin{array}{l}0.00001 \\
(0.0018)\end{array}$ \\
\hline $\begin{array}{l}\text { Public state or } \\
\text { local } \times \text { dry }\end{array}$ & $\begin{array}{c}0.0041 \\
(0.0035)\end{array}$ & $\begin{array}{c}0.0043 \\
(0.0065)\end{array}$ & $\begin{array}{c}0.0070 \\
(0.0025)^{* * *}\end{array}$ & $\begin{array}{c}0.0053 \\
(0.0049)\end{array}$ & $\begin{array}{c}0.0085 \\
(0.0037)^{* *}\end{array}$ & $\begin{array}{c}0.0035 \\
(0.0048) \\
\end{array}$ & $\begin{array}{c}0.0012 \\
(0.0087)\end{array}$ \\
\hline $\begin{array}{l}\text { Public state or } \\
\text { local } \times \\
\text { proximity }\end{array}$ & $\begin{array}{c}0.280 \\
(0.092)^{* * *}\end{array}$ & $\begin{array}{c}0.209 \\
(0.097)^{* *}\end{array}$ & $\begin{array}{c}0.163 \\
(0.062)^{* *}\end{array}$ & $\begin{array}{c}0.364 \\
(0.102)^{* * *}\end{array}$ & $\begin{array}{c}0.288 \\
(0.092)^{* * *}\end{array}$ & $\begin{array}{c}0.489 \\
(0.154)^{* * *}\end{array}$ & $\begin{array}{c}0.231 \\
(0.126)^{*}\end{array}$ \\
\hline $\begin{array}{l}\text { Public state or } \\
\text { local } \times \\
\text { density }\end{array}$ & $\begin{array}{c}0.033 \\
(0.007)^{* * *}\end{array}$ & $\begin{array}{c}0.047 \\
(0.007)^{* * *}\end{array}$ & $\begin{array}{c}0.031 \\
(0.005)^{* * *}\end{array}$ & $\begin{array}{c}0.012 \\
(0.009)\end{array}$ & $\begin{array}{c}0.039 \\
(0.007)^{* * *}\end{array}$ & $\begin{array}{c}0.011 \\
(0.012)\end{array}$ & $\begin{array}{c}0.030 \\
(0.010)^{* * *}\end{array}$ \\
\hline $\begin{array}{l}\text { Joint } \\
\text { significance } \\
(p \text {-value }) \\
\end{array}$ & $<0.001$ & $<0.001$ & $<0.001$ & $<0.001$ & $<0.001$ & $<0.001$ & $<0.001$ \\
\hline $\begin{array}{l}\text { Mild + } \\
\text { interaction }\end{array}$ & $\begin{array}{l}-0.0009 \\
(0.0004)^{* *}\end{array}$ & $\begin{array}{c}-0.0025 \\
(0.0014)^{*}\end{array}$ & $\begin{array}{c}-0.0012 \\
(0.0004)^{* * *}\end{array}$ & $\begin{array}{c}-0.0024 \\
(0.0008)^{* * *}\end{array}$ & $\begin{array}{c}-0.0008 \\
(0.0005)^{*}\end{array}$ & $\begin{array}{c}-0.0022 \\
(0.0013)^{*}\end{array}$ & $\begin{array}{c}-0.0033 \\
(0.0019)^{*}\end{array}$ \\
\hline $\begin{array}{l}\text { Dry + } \\
\text { interaction }\end{array}$ & $\begin{array}{c}0.0042 \\
(0.0046)\end{array}$ & $\begin{array}{c}-0.0061 \\
(0.0074)\end{array}$ & $\begin{array}{c}0.0047 \\
(0.0032) \\
\end{array}$ & $\begin{array}{c}0.0068 \\
(0.0060) \\
\end{array}$ & $\begin{array}{c}0.0080 \\
(0.0047)^{*}\end{array}$ & $\begin{array}{c}0.0057 \\
(0.0049) \\
\end{array}$ & $\begin{array}{c}0.0028 \\
(0.0087)\end{array}$ \\
\hline $\begin{array}{l}\text { Proximity + } \\
\text { interaction }\end{array}$ & $\begin{array}{c}0.257 \\
(0.069)^{* * *}\end{array}$ & $\begin{array}{c}0.170 \\
(0.101)^{*}\end{array}$ & $\begin{array}{c}0.125 \\
(0.059)^{* *}\end{array}$ & $\begin{array}{c}0.381 \\
(0.066)^{* * *}\end{array}$ & $\begin{array}{c}0.282 \\
(0.073)^{* * *}\end{array}$ & $\begin{array}{c}0.441 \\
(0.139)^{* * *}\end{array}$ & $\begin{array}{c}0.264 \\
(0.143)^{* *}\end{array}$ \\
\hline $\begin{array}{l}\text { Density + } \\
\text { interaction }\end{array}$ & $\begin{array}{c}0.022 \\
(0.010)^{* *}\end{array}$ & $\begin{array}{c}0.008 \\
(0.009)\end{array}$ & $\begin{array}{c}0.010 \\
(0.007)\end{array}$ & $\begin{array}{c}0.013 \\
(0.013)\end{array}$ & $\begin{array}{c}0.023 \\
(0.010)^{* *}\end{array}$ & $\begin{array}{c}0.010 \\
(0.013)\end{array}$ & $\begin{array}{c}0.012 \\
(0.010)\end{array}$ \\
\hline $\mathrm{N}$ & $1,265,334$ & 331,712 & $1,184,290$ & 412,756 & $1,294,598$ & 146,909 & 159,851 \\
\hline
\end{tabular}

Notes: See notes to Tables 3-5. Specification and sample, aside from restrictions noted in column heading, are the same as in column (7) of Table 5.

Sources: CPS ORG files, 1994-2005; 2000 Census 5\% sample. 
Table 7: Wage Regressions with Public Sector-Amenity Interactions, for Public State (Only) Workers

\begin{tabular}{|c|c|c|c|c|c|c|c|c|}
\hline & \multicolumn{6}{|c|}{ Union and nonunion public-sector workers vs. all workers } & \multicolumn{2}{|c|}{$\begin{array}{l}\text { Only union public-sector } \\
\text { workers vs. all workers }\end{array}$} \\
\hline & (1) & $(2)$ & (3) & (4) & (5) & $(6)$ & $(7)$ & $(8)$ \\
\hline Mild & $\begin{array}{l}-0.0001 \\
(0.0012)\end{array}$ & & & & $\begin{array}{l}-0.0004 \\
(0.0005)\end{array}$ & $\begin{array}{l}-0.0013 \\
(0.0005)^{* *}\end{array}$ & $\begin{array}{l}-0.0004 \\
(0.0005)\end{array}$ & $\begin{array}{l}-0.0013 \\
(0.0005)^{* *}\end{array}$ \\
\hline Dry & & $\begin{array}{c}0.009 \\
(0.003)^{* *}\end{array}$ & & & $\begin{array}{c}0.011 \\
(0.002)^{* * *}\end{array}$ & $\begin{array}{l}-0.001 \\
(0.002)\end{array}$ & $\begin{array}{c}0.011 \\
(0.002)^{* * *}\end{array}$ & $\begin{array}{l}-0.0009 \\
(0.0023)\end{array}$ \\
\hline Proximity & & & $\begin{array}{c}0.095 \\
(0.061) \\
\end{array}$ & & $\begin{array}{c}0.116 \\
(0.036)^{* * *}\end{array}$ & $\begin{array}{l}-0.023 \\
(0.027)\end{array}$ & $\begin{array}{c}0.118 \\
(0.037)^{* * *}\end{array}$ & $\begin{array}{l}-0.020 \\
(0.027)\end{array}$ \\
\hline Density & & & & $\begin{array}{c}0.022 \\
(0.014) \\
\end{array}$ & $\begin{array}{c}0.014 \\
(0.007)^{* *}\end{array}$ & $\begin{array}{l}-0.013 \\
(0.004)^{* * *}\end{array}$ & $\begin{array}{c}0.014 \\
(0.007)^{* *}\end{array}$ & $\begin{array}{l}-0.013 \\
(0.004)^{* * *}\end{array}$ \\
\hline $\begin{array}{l}\text { Public state or } \\
\text { local }\end{array}$ & $\begin{array}{l}-0.042 \\
(0.008)^{* * *}\end{array}$ & $\begin{array}{l}-0.042 \\
(0.008)^{* * *}\end{array}$ & $\begin{array}{l}-0.039 \\
(0.006)^{* * *}\end{array}$ & $\begin{array}{l}-0.038 \\
(0.009)^{* * *}\end{array}$ & $\begin{array}{l}-0.035 \\
(0.007)^{* * *}\end{array}$ & $\begin{array}{l}-0.034 \\
(0.007)^{* * *}\end{array}$ & $\begin{array}{l}-0.050 \\
(0.011)^{* * *}\end{array}$ & $\begin{array}{l}-0.054 \\
(0.012)^{* * *}\end{array}$ \\
\hline $\begin{array}{l}\text { Housing price } \\
\text { premium } \\
(\$ 1,000 \mathrm{~s})\end{array}$ & & & & & & $\begin{array}{c}0.022 \\
(0.003)^{* * *}\end{array}$ & & $\begin{array}{c}0.022 \\
(0.003)^{* * *}\end{array}$ \\
\hline $\begin{array}{l}\text { Public state or } \\
\text { local } \times \text { mild }\end{array}$ & $\begin{array}{l}-0.00001 \\
(0.0007)\end{array}$ & & & & $\begin{array}{c}0.0003 \\
(0.0005)\end{array}$ & $\begin{array}{c}0.0003 \\
(0.0005)\end{array}$ & $\begin{array}{l}-0.0005 \\
(0.0007)\end{array}$ & $\begin{array}{l}-0.0005 \\
(0.0007)\end{array}$ \\
\hline $\begin{array}{l}\text { Public state or } \\
\text { local } \times \text { dry }\end{array}$ & & $\begin{array}{c}0.0010 \\
(0.0031)\end{array}$ & & & $\begin{array}{c}0.0020 \\
(0.0018)\end{array}$ & $\begin{array}{c}0.0027 \\
(0.0016)^{*}\end{array}$ & $\begin{array}{c}0.0083 \\
(0.0036)^{* *}\end{array}$ & $\begin{array}{c}0.0097 \\
(0.0037)^{* *}\end{array}$ \\
\hline $\begin{array}{l}\text { Public state or } \\
\text { local } \times \\
\text { proximity }\end{array}$ & & & $\begin{array}{c}0.096 \\
(0.033)^{* * *}\end{array}$ & & $\begin{array}{c}0.090 \\
(0.036)^{* *}\end{array}$ & $\begin{array}{c}0.106 \\
(0.042)^{* *}\end{array}$ & $\begin{array}{c}0.355 \\
(0.100)^{* * *}\end{array}$ & $\begin{array}{c}0.339 \\
(0.105)^{* * *}\end{array}$ \\
\hline $\begin{array}{l}\text { Public state or } \\
\text { local } \times \text { density }\end{array}$ & & & & $\begin{array}{c}0.026 \\
(0.010)^{* *}\end{array}$ & $\begin{array}{c}0.018 \\
(0.007)^{* * *}\end{array}$ & $\begin{array}{c}0.016 \\
(0.005)^{* * *}\end{array}$ & $\begin{array}{l}0.016 \\
(0.007)^{* *}\end{array}$ & $\begin{array}{c}0.021 \\
(0.007)^{* * *}\end{array}$ \\
\hline $\begin{array}{l}\text { Joint } \\
\text { significance } \\
\text { (p-value) }\end{array}$ & & & & & $<0.001$ & $<0.001$ & $<0.001$ & $<0.001$ \\
\hline $\begin{array}{l}\text { Mild + } \\
\text { interaction }\end{array}$ & $\begin{array}{l}-0.0001 \\
(0.0017)\end{array}$ & & & & $\begin{array}{l}-0.0001 \\
(0.0007)\end{array}$ & $\begin{array}{l}-0.0010 \\
(0.0004)^{* *}\end{array}$ & $\begin{array}{l}-0.0009 \\
(0.0008)\end{array}$ & $\begin{array}{l}-0.0019 \\
(0.0005)^{* * *}\end{array}$ \\
\hline $\begin{array}{l}\text { Dry + } \\
\text { interaction }\end{array}$ & & $\begin{array}{c}0.0099 \\
(0.0056)^{*}\end{array}$ & & & $\begin{array}{c}0.0126 \\
(0.0029)^{* * *}\end{array}$ & $\begin{array}{c}0.0016 \\
(0.0025)\end{array}$ & $\begin{array}{c}0.0189 \\
(0.0044)^{* * *}\end{array}$ & $\begin{array}{c}0.0088 \\
(0.0044)^{*}\end{array}$ \\
\hline $\begin{array}{l}\text { Proximity + } \\
\text { interaction }\end{array}$ & & & $\begin{array}{c}0.190 \\
(0.084)^{* *}\end{array}$ & & $\begin{array}{c}0.206 \\
(0.060)^{* * *}\end{array}$ & $\begin{array}{c}0.082 \\
(0.033)^{* *}\end{array}$ & $\begin{array}{c}0.473 \\
(0.125)^{* * *}\end{array}$ & $\begin{array}{c}0.319 \\
(0.092)^{* * *}\end{array}$ \\
\hline $\begin{array}{l}\text { Density + } \\
\text { interaction }\end{array}$ & & & & $\begin{array}{c}0.048 \\
(0.023)^{* *}\end{array}$ & $\begin{array}{c}0.032 \\
(0.012)^{* *}\end{array}$ & $\begin{array}{c}0.003 \\
(0.007) \\
\end{array}$ & $\begin{array}{c}0.031 \\
(0.012)^{* *}\end{array}$ & $\begin{array}{c}0.008 \\
(0.009) \\
\end{array}$ \\
\hline $\mathrm{N}$ & $1,591,154$ & $1,591,154$ & $1,591,154$ & $1,591,154$ & $1,591,154$ & $1,591,154$ & $1,529,594$ & $1,529,594$ \\
\hline
\end{tabular}

Notes: See notes to Tables 3-5. The only difference relative to Table 5 is that public local workers are omitted.

Sources: CPS ORG files, 1994-2005; 2000 Census 5\% sample. 
Table 8: Wage Regressions with Public Sector-Amenity Interactions, with Fixed State Effects

\begin{tabular}{|c|c|c|c|c|}
\hline & \multicolumn{2}{|c|}{ Public state or local } & \multicolumn{2}{|c|}{ Public state only } \\
\hline & $\begin{array}{c}\text { Union and nonunion } \\
\text { public-sector workers } \\
\text { vs. all workers } \\
\end{array}$ & $\begin{array}{l}\text { Only union public- } \\
\text { sector workers vs. } \\
\text { all workers } \\
\end{array}$ & $\begin{array}{c}\text { Union and nonunion } \\
\text { public-sector workers } \\
\text { vs. all workers } \\
\end{array}$ & $\begin{array}{l}\text { Only union public- } \\
\text { sector workers vs. } \\
\text { all workers } \\
\end{array}$ \\
\hline & $(1)$ & $(2)$ & $(3)$ & $(4)$ \\
\hline $\begin{array}{l}\text { Public state or } \\
\text { local }\end{array}$ & $\begin{array}{l}-0.041 \\
(0.007)^{* * *}\end{array}$ & $\begin{array}{l}-0.058 \\
(0.012)^{* * *}\end{array}$ & $\begin{array}{l}-0.033 \\
(0.007)^{* * *}\end{array}$ & $\begin{array}{l}-0.053 \\
(0.012)^{* * *}\end{array}$ \\
\hline $\begin{array}{l}\text { Public state or } \\
\text { local } \times \text { mild }\end{array}$ & $\begin{array}{c}0.0010 \\
(0.0006)^{*}\end{array}$ & $\begin{array}{c}0.0007 \\
(0.0007)\end{array}$ & $\begin{array}{c}0.0001 \\
(0.0005)\end{array}$ & $\begin{array}{l}-0.0006 \\
(0.0007)\end{array}$ \\
\hline $\begin{array}{l}\text { Public state or } \\
\text { local } \times \text { dry }\end{array}$ & $\begin{array}{c}0.0026 \\
(0.0025) \\
\end{array}$ & $\begin{array}{c}0.0056 \\
(0.0039) \\
\end{array}$ & $\begin{array}{c}0.0033 \\
(0.0015)^{* *}\end{array}$ & $\begin{array}{c}0.0097 \\
(0.0037)^{* *}\end{array}$ \\
\hline $\begin{array}{l}\text { Public state or } \\
\text { local } \times \\
\text { proximity }\end{array}$ & $\begin{array}{c}0.109 \\
(0.052)^{* *}\end{array}$ & $\begin{array}{c}0.305 \\
(0.099)^{* * *}\end{array}$ & $\begin{array}{c}0.099 \\
(0.038)^{* *}\end{array}$ & $\begin{array}{c}0.323 \\
(0.104)^{* * *}\end{array}$ \\
\hline $\begin{array}{l}\text { Public state or } \\
\text { local } \times \text { density }\end{array}$ & $\begin{array}{c}0.028 \\
(0.004)^{* * *}\end{array}$ & $\begin{array}{c}0.037 \\
(0.007)^{* * *}\end{array}$ & $\begin{array}{c}0.015 \\
(0.005)^{* * *}\end{array}$ & $\begin{array}{c}0.020 \\
(0.007)^{* * *}\end{array}$ \\
\hline $\begin{array}{l}\text { Joint } \\
\text { significance } \\
\text { (p-value) }\end{array}$ & $<0.001$ & $<0.001$ & $<0.001$ & $<0.001$ \\
\hline
\end{tabular}

Notes: See notes to Tables 3-5. Specifications correspond to columns (5) and (7) of Tables 5 and 7. The only difference is that state fixed effects are added, which result in the main effects of the amenity and housing cost variables being dropped from the regression equations.

Sources: CPS ORG files, 1994-2005; 2000 Census 5\% sample. 
Table 9: Wage Regressions with Public Sector-Amenity Interactions, Adding State Democratic Vote Share and its Interaction with Public-Sector Status

\begin{tabular}{|c|c|c|c|c|}
\hline & \multicolumn{2}{|c|}{ Public state or local } & \multicolumn{2}{|c|}{ Public state only } \\
\hline & $\begin{array}{l}\text { Union and nonunion } \\
\text { public-sector workers } \\
\text { vs. all workers } \\
\end{array}$ & $\begin{array}{c}\text { Only union public- } \\
\text { sector workers vs. } \\
\text { all workers } \\
\end{array}$ & $\begin{array}{c}\text { Union and nonunion } \\
\text { public-sector workers } \\
\text { vs. all workers } \\
\end{array}$ & $\begin{array}{l}\text { Only union public- } \\
\text { sector workers vs. } \\
\text { all workers } \\
\end{array}$ \\
\hline & $(1)$ & $(2)$ & (3) & $(4)$ \\
\hline \multicolumn{5}{|c|}{ Using state vote share for Michael Dukakis, 1988} \\
\hline $\begin{array}{l}\text { Public state or } \\
\text { local }\end{array}$ & $\begin{array}{l}-0.042 \\
(0.006)^{* * *}\end{array}$ & $\begin{array}{c}-0.057 \\
(0.011)^{* * *}\end{array}$ & $(0.007)^{* * *}$ & $\begin{array}{l}-0.049 \\
(0.012)^{* * *}\end{array}$ \\
\hline Vote share & $\begin{array}{c}0.0016 \\
(0.0022) \\
\end{array}$ & $\begin{array}{c}0.0015 \\
(0.0022) \\
\end{array}$ & $\begin{array}{c}0.0015 \\
(0.0022) \\
\end{array}$ & $\begin{array}{c}0.0015 \\
(0.0022) \\
\end{array}$ \\
\hline $\begin{array}{l}\text { Public state or } \\
\text { local } \times \text { vote share }\end{array}$ & $\begin{array}{l}-0.0025 \\
(0.0017)\end{array}$ & $\begin{array}{l}-0.0038 \\
(0.0031)\end{array}$ & $\begin{array}{l}-0.0008 \\
(0.0017)\end{array}$ & $\begin{array}{l}-0.0036 \\
(0.0028)\end{array}$ \\
\hline $\begin{array}{l}\text { Public state or } \\
\text { local } \times \text { mild }\end{array}$ & $\begin{array}{c}0.0007 \\
(0.0006)\end{array}$ & $\begin{array}{l}-0.00004 \\
(0.0008) \\
\end{array}$ & $\begin{array}{c}0.0001 \\
(0.0005)\end{array}$ & $\begin{array}{l}-0.0010 \\
(0.0007)\end{array}$ \\
\hline $\begin{array}{l}\text { Public state or } \\
\text { local } \times \text { dry }\end{array}$ & $\begin{array}{c}0.0043 \\
(0.0024)^{*}\end{array}$ & $\begin{array}{c}0.0086 \\
(0.0032)^{* * *}\end{array}$ & $\begin{array}{c}0.0027 \\
(0.0023)\end{array}$ & $\begin{array}{c}0.0104 \\
(0.0033)^{* * *}\end{array}$ \\
\hline $\begin{array}{l}\text { Public state or } \\
\text { local } \times \text { proximity }\end{array}$ & $\begin{array}{c}0.126 \\
(0.056)^{* *}\end{array}$ & $\begin{array}{c}0.358 \\
(0.109)^{* * *}\end{array}$ & $\begin{array}{c}0.097 \\
(0.044)^{* *}\end{array}$ & $\begin{array}{c}0.389 \\
(0.110)^{* * *}\end{array}$ \\
\hline $\begin{array}{l}\text { Public state or } \\
\text { local } \times \text { density }\end{array}$ & $\begin{array}{c}0.035 \\
(0.005)^{* * *}\end{array}$ & $\begin{array}{c}0.043 \\
(0.007)^{* * *}\end{array}$ & $\begin{array}{c}0.020 \\
(0.008)^{* *}\end{array}$ & $\begin{array}{c}0.024 \\
(0.008)^{* * *} \\
\end{array}$ \\
\hline $\begin{array}{l}\text { Joint significance } \\
\text { (p-value) }\end{array}$ & $<0.001$ & $<0.001$ & 0.023 & 0.001 \\
\hline \multicolumn{5}{|c|}{ Using state vote share for Bill Clinton, 1992} \\
\hline $\begin{array}{l}\text { Public state or } \\
\text { local }\end{array}$ & $\begin{array}{l}-0.042 \\
(0.007)^{* * *}\end{array}$ & $\begin{array}{c}-0.058 \\
(0.012)^{* * *}\end{array}$ & $\begin{array}{c}-0.034 \\
(0.007)^{* * *}\end{array}$ & $\begin{array}{l}-0.051 \\
(0.012)^{* * *}\end{array}$ \\
\hline Vote share & $\begin{array}{c}0.0045 \\
(0.0016)^{* * *}\end{array}$ & $\begin{array}{c}0.0045 \\
(0.0016)^{* * *}\end{array}$ & $\begin{array}{c}0.0045 \\
(0.0016)^{* * *}\end{array}$ & $\begin{array}{c}0.0045 \\
(0.0016)^{* * *}\end{array}$ \\
\hline $\begin{array}{l}\text { Public state or } \\
\text { local } \times \text { vote share }\end{array}$ & $\begin{array}{c}0.0008 \\
(0.0016)\end{array}$ & $\begin{array}{c}0.0006 \\
(0.0026)\end{array}$ & $\begin{array}{c}0.0020 \\
(0.0014)\end{array}$ & $\begin{array}{c}0.0014 \\
(0.0029)\end{array}$ \\
\hline $\begin{array}{l}\text { Public state or } \\
\text { local } \times \text { mild }\end{array}$ & $\begin{array}{c}0.0011 \\
(0.0006)^{*}\end{array}$ & $\begin{array}{r}0.0006 \\
(0.0006) \\
\end{array}$ & $\begin{array}{r}0.0003 \\
(0.0004) \\
\end{array}$ & $\begin{array}{l}-0.0005 \\
(0.0007) \\
\end{array}$ \\
\hline $\begin{array}{l}\text { Public state or } \\
\text { local } \times \text { dry }\end{array}$ & $\begin{array}{c}0.0024 \\
(0.0022)\end{array}$ & $\begin{array}{c}0.0054 \\
(0.0032)\end{array}$ & $\begin{array}{c}0.0021 \\
(0.0017)\end{array}$ & $\begin{array}{c}0.0081 \\
(0.0035)^{* *}\end{array}$ \\
\hline $\begin{array}{l}\text { Public state or } \\
\text { local } \times \text { proximity }\end{array}$ & $\begin{array}{c}0.096 \\
(0.048)^{*} \\
\end{array}$ & $\begin{array}{c}0.313 \\
(0.112)^{* * *} \\
\end{array}$ & $\begin{array}{c}0.066 \\
(0.033)^{* *}\end{array}$ & $\begin{array}{c}0.333 \\
(0.119)^{* * *}\end{array}$ \\
\hline $\begin{array}{l}\text { Public state or } \\
\text { local } \times \text { density }\end{array}$ & $\begin{array}{l}0.027 \\
(0.006)^{* * *}\end{array}$ & $\begin{array}{c}0.033 \\
(0.008)^{* * *}\end{array}$ & $\begin{array}{c}0.012 \\
(0.008)\end{array}$ & $\begin{array}{c}0.014 \\
(0.008)^{*}\end{array}$ \\
\hline $\begin{array}{l}\text { Joint significance } \\
\text { (p-value) }\end{array}$ & $<0.001$ & $<0.001$ & 0.200 & 0.019 \\
\hline
\end{tabular}

Notes: See notes to Tables 3-5. Specifications correspond to columns (5) and (7) of Tables 5 and 7. The only difference is that the state Democratic vote share (0-100) and its interaction with public-sector status are added. The vote share variables are demeaned (based on the same population weights used for the regression, and using the same sample), so that the main effects capture the effect at the sample means. The main effects of the amenities and the sums of the main plus interactive effects are not reported; they were very similar to the corresponding estimates in Tables 5 and 7. The estimates with the housing cost variable added were also very similar to those in Tables 5 and 7. Sources: CPS ORG files, 1994-2005; 2000 Census 5\% sample. Democratic vote share from uselectionatlas.org (viewed May 2, 2012). 
Table 10: Descriptive Statistics on Distribution of Teachers by Sector and Union Membership

\begin{tabular}{|l|c|}
\hline Public state or local & 0.758 \\
\hline Public state only & 0.096 \\
\hline Public federal & 0.007 \\
\hline Union member & 0.552 \\
\hline $\begin{array}{l}\text { Union member and public state or } \\
\text { local }\end{array}$ & 0.507 \\
\hline $\begin{array}{l}\text { Union member and public state } \\
\text { only }\end{array}$ & 0.054 \\
\hline Union member and public federal & 0.003 \\
\hline
\end{tabular}

Notes: The sample is restricted to elementary and secondary school teachers, defined based on the following Census of Population occupational codes: for 2002 and earlier (1990 Census codes), teachers in kindergarten or pre-kindergarten (155), elementary school (156), secondary school (157), or special education (158); and for 2003 and after (2002 Census codes), preschool and kindergarten teachers (2300), elementary and middle school teachers (2310), secondary school teachers (2320), and special education teachers (2330). The sample size is 68,127. See notes to Table 1.

Source: CPS ORG files, 1994-2005. 
Table 11: Wage Regressions with Public Sector-Amenity Interactions, for Public State or Local Teachers

\begin{tabular}{|c|c|c|c|c|c|c|}
\hline & \multicolumn{3}{|c|}{$\begin{array}{l}\text { Union and nonunion public-sector } \\
\text { teachers vs. others }\end{array}$} & \multicolumn{3}{|c|}{$\begin{array}{l}\text { Only union public-sector teachers } \\
\text { vs. others }\end{array}$} \\
\hline & $(1)$ & $(2)$ & $(3)$ & $(4)$ & (5) & (6) \\
\hline Mild & $\begin{array}{l}-0.0004 \\
(0.0005)\end{array}$ & $\begin{array}{l}-0.0013 \\
(0.0005)^{* *}\end{array}$ & $\begin{array}{l}-0.0011 \\
(0.0005)^{* *}\end{array}$ & $\begin{array}{l}-0.0004 \\
(0.0005)\end{array}$ & $\begin{array}{l}-0.0013 \\
(0.0005)^{* *}\end{array}$ & $\begin{array}{l}-0.0011 \\
(0.0005)^{* *}\end{array}$ \\
\hline Dry & $\begin{array}{l}0.0104 \\
(0.0025)^{* * *}\end{array}$ & $\begin{array}{l}-0.0012 \\
(0.0024)\end{array}$ & $\begin{array}{c}0.0024 \\
(0.0028) \\
\end{array}$ & $\begin{array}{c}0.0105 \\
(0.0025)^{* * *}\end{array}$ & $\begin{array}{l}-0.0011 \\
(0.0024)\end{array}$ & $\begin{array}{c}0.0026 \\
(0.0029) \\
\end{array}$ \\
\hline Proximity & $\begin{array}{c}0.113 \\
(0.035)^{* * *}\end{array}$ & $\begin{array}{l}-0.026 \\
(0.028)\end{array}$ & $\begin{array}{l}-0.005 \\
(0.021)\end{array}$ & $\begin{array}{c}0.116 \\
(0.036)^{* * *}\end{array}$ & $\begin{array}{l}-0.022 \\
(0.027)\end{array}$ & $\begin{array}{l}-0.002 \\
(0.021)\end{array}$ \\
\hline Density & $\begin{array}{l}0.014 \\
(0.007)^{* *}\end{array}$ & $\begin{array}{c}-0.013 \\
(0.004)^{* * *}\end{array}$ & $\begin{array}{l}-0.020 \\
(0.004)^{* * *}\end{array}$ & $\begin{array}{c}0.014 \\
(0.007)^{* *}\end{array}$ & $\begin{array}{c}-0.013 \\
(0.004)^{* * *}\end{array}$ & $\begin{array}{c}-0.019 \\
(0.004)^{* * *}\end{array}$ \\
\hline Public state or local & $\begin{array}{c}0.108 \\
(0.019)^{* * *}\end{array}$ & $\begin{array}{c}0.109 \\
(0.018)^{* * *}\end{array}$ & $\begin{array}{c}0.109 \\
(0.019)^{* * *}\end{array}$ & $\begin{array}{c}0.103 \\
(0.019)^{* * *}\end{array}$ & $\begin{array}{c}0.103 \\
(0.019)^{* * *}\end{array}$ & $\begin{array}{c}0.103 \\
(0.020)^{* * *}\end{array}$ \\
\hline Teacher & $\begin{array}{l}-0.179 \\
(0.016)^{* * *}\end{array}$ & $\begin{array}{l}-0.177 \\
(0.016)^{* * *}\end{array}$ & $\begin{array}{l}-0.178 \\
(0.016)^{* * *}\end{array}$ & $\begin{array}{l}-0.179 \\
(0.016)^{* * *}\end{array}$ & $\begin{array}{l}-0.177 \\
(0.016)^{* * *}\end{array}$ & $\begin{array}{l}-0.177 \\
(0.016)^{* * *}\end{array}$ \\
\hline $\begin{array}{l}\text { Housing price premium } \\
(\$ 1,000 \mathrm{~s})\end{array}$ & & $\begin{array}{c}0.022 \\
(0.003)^{* * *}\end{array}$ & $\begin{array}{c}0.024 \\
(0.002)^{* * *}\end{array}$ & & $\begin{array}{c}0.022 \\
(0.003)^{* * *}\end{array}$ & $\begin{array}{c}0.024 \\
(0.002)^{* * *}\end{array}$ \\
\hline Student-teacher ratio & & & $\begin{array}{l}-0.005 \\
(0.002)^{* *}\end{array}$ & & & $\begin{array}{l}-0.005 \\
(0.002)^{* *}\end{array}$ \\
\hline $\begin{array}{l}\text { Student-teacher ratio } \times \\
\text { public teacher }\end{array}$ & & & $\begin{array}{c}0.0011 \\
(0.0054)\end{array}$ & & & $\begin{array}{c}0.0054 \\
(0.0089)\end{array}$ \\
\hline $\begin{array}{l}\text { Public state or local } \times \\
\text { mild }\end{array}$ & $\begin{array}{c}0.0017 \\
(0.0007)^{* *}\end{array}$ & $\begin{array}{c}0.0020 \\
(0.0007)^{* * *}\end{array}$ & $\begin{array}{l}0.0019 \\
(0.0007)^{* * *}\end{array}$ & $\begin{array}{c}0.0004 \\
(0.0011)\end{array}$ & $\begin{array}{c}0.0006 \\
(0.0011)\end{array}$ & $\begin{array}{c}0.0003 \\
(0.0012)\end{array}$ \\
\hline $\begin{array}{l}\text { Public state or local } \times \\
\text { dry }\end{array}$ & $\begin{array}{c}0.0023 \\
(0.0028)\end{array}$ & $\begin{array}{c}0.0017 \\
(0.0026) \\
\end{array}$ & $\begin{array}{c}0.0006 \\
(0.0051) \\
\end{array}$ & $\begin{array}{c}0.0085 \\
(0.0051) \\
\end{array}$ & $\begin{array}{c}0.0077 \\
(0.0052) \\
\end{array}$ & $\begin{array}{c}0.0026 \\
(0.0076)\end{array}$ \\
\hline $\begin{array}{l}\text { Public state or local } \times \\
\text { proximity }\end{array}$ & $\begin{array}{c}0.253 \\
(0.056)^{* * *}\end{array}$ & $\begin{array}{l}0.246 \\
(0.056)^{* * *}\end{array}$ & $\begin{array}{l}0.240 \\
(0.076)^{* * *}\end{array}$ & $\begin{array}{c}0.474 \\
(0.130)^{* * *}\end{array}$ & $\begin{array}{c}0.469 \\
(0.130)^{* * *}\end{array}$ & $\begin{array}{c}0.433 \\
(0.137)^{* * *}\end{array}$ \\
\hline $\begin{array}{l}\text { Public state or local } \times \\
\text { density }\end{array}$ & $\begin{array}{c}0.069 \\
(0.009)^{* * *}\end{array}$ & $\begin{array}{c}0.066 \\
(0.009)^{* * *}\end{array}$ & $\begin{array}{c}0.068 \\
(0.010)^{* * *}\end{array}$ & $\begin{array}{c}0.068 \\
(0.012)^{* * *}\end{array}$ & $\begin{array}{c}0.069 \\
(0.012)^{* * *}\end{array}$ & $\begin{array}{c}0.074 \\
(0.015)^{* * *}\end{array}$ \\
\hline $\begin{array}{l}\text { Joint significance (p- } \\
\text { value) }\end{array}$ & $<0.001$ & $<0.001$ & $<0.001$ & $<0.001$ & $<0.001$ & $<0.001$ \\
\hline Mild + interaction & $\begin{array}{c}0.0013 \\
(0.0009) \\
\end{array}$ & $\begin{array}{c}0.0007 \\
(0.0007)\end{array}$ & $\begin{array}{c}0.0008 \\
(0.0007)\end{array}$ & $\begin{array}{l}-0.00001 \\
(0.0012) \\
\end{array}$ & $\begin{array}{l}-0.0007 \\
(0.0009)\end{array}$ & $\begin{array}{l}-0.0008 \\
(0.0010)\end{array}$ \\
\hline Dry + interaction & $\begin{array}{c}0.0128 \\
(0.0039)^{* * *}\end{array}$ & $\begin{array}{c}0.0005 \\
(0.0038)\end{array}$ & $\begin{array}{c}0.0031 \\
(0.0053)\end{array}$ & $\begin{array}{c}0.0190 \\
(0.0057)^{* * *}\end{array}$ & $\begin{array}{c}0.0066 \\
(0.0060)\end{array}$ & $\begin{array}{c}0.0052 \\
(0.0072)\end{array}$ \\
\hline Proximity + interaction & $\begin{array}{c}0.366 \\
(0.074)^{* * *}\end{array}$ & $\begin{array}{c}0.220 \\
(0.046)^{* * *}\end{array}$ & $\begin{array}{c}0.235 \\
(0.073)^{* * *}\end{array}$ & $\begin{array}{c}0.591 \\
(0.151)^{* * *}\end{array}$ & $\begin{array}{c}0.447 \\
(0.114)^{* * *}\end{array}$ & $\begin{array}{c}0.431 \\
(0.132)^{* * *}\end{array}$ \\
\hline Density + interaction & $\begin{array}{c}0.081 \\
(0.015)^{* * *}\end{array}$ & $\begin{array}{c}0.053 \\
(0.011)^{* * *}\end{array}$ & $\begin{array}{c}0.048 \\
(0.011)^{* * *}\end{array}$ & $\begin{array}{c}0.082 \\
(0.017)^{* * *}\end{array}$ & $\begin{array}{c}0.056 \\
(0.014)^{* * * *}\end{array}$ & $\begin{array}{c}0.055 \\
(0.016)^{* * *}\end{array}$ \\
\hline $\mathrm{N}$ & $1,555,101$ & $1,555,101$ & $1,555,101$ & $1,535,822$ & $1,535,822$ & $1,535,822$ \\
\hline
\end{tabular}

Notes: See notes to Tables 3-5. The only difference relative to Table 5 is that only teachers are included among public-sector workers. The student-teacher ratio is demeaned (based on the same population weights used for the regression, and using the same sample), so that the main effects capture the effect at the sample means.

Sources: CPS ORG files, 1994-2005; 2000 Census 5\% sample; student-teacher ratios are for 2007-8, and are taken from http://www.nea.org/home/29402.htm (viewed October 13, 2010). 
Table 12: Descriptive Statistics on Distribution of Corrections Officers by Sector and Union Membership

\begin{tabular}{|l|c|}
\hline Public state or local & 0.949 \\
\hline Public state only & 0.481 \\
\hline Public federal & 0.051 \\
\hline Union member & 0.562 \\
\hline $\begin{array}{l}\text { Union member and public state or } \\
\text { local }\end{array}$ & 0.541 \\
\hline $\begin{array}{l}\text { Union member and public state } \\
\text { only }\end{array}$ & 0.292 \\
\hline Union member and public federal & 0.022 \\
\hline
\end{tabular}

Notes: The sample is restricted to corrections officers, defined based on the following Census of Population occupational codes: for 2002 and earlier (1990 Census codes), sheriffs, bailiffs, and other law enforcement officers (423, which does not include police), and correctional institution officers (424); for 2003 and after (2002 Census codes), first-line supervisors/managers of correctional officers (3700), and bailiffs, correctional officers, and jailers (3800). The sample size is 6,631. See notes to Table 1. Source: CPS ORG files, 1994-2005. 
Table 13: Wage Regressions with Public Sector-Amenity Interactions, for Public State or Local Corrections Officers

\begin{tabular}{|c|c|c|c|c|c|c|}
\hline & \multicolumn{3}{|c|}{$\begin{array}{l}\text { Union and nonunion public-sector } \\
\text { corrections officers vs. others }\end{array}$} & \multicolumn{3}{|c|}{$\begin{array}{l}\text { Only union public-sector corrections } \\
\text { officers vs. others }\end{array}$} \\
\hline & $(1)$ & $(2)$ & (3) & $(4)$ & $(5)$ & (6) \\
\hline Mild & $\begin{array}{l}-0.0004 \\
(0.0005)\end{array}$ & $\begin{array}{l}-0.0013 \\
(0.0005)^{* *}\end{array}$ & $\begin{array}{l}-0.0012 \\
(0.0006)^{*}\end{array}$ & $\begin{array}{l}-0.0004 \\
(0.0005)\end{array}$ & $\begin{array}{l}-0.0013 \\
(0.0005)^{* *}\end{array}$ & $\begin{array}{l}-0.0012 \\
(0.0006)^{*}\end{array}$ \\
\hline Dry & $\begin{array}{c}0.0106 \\
(0.0025)^{* * *}\end{array}$ & $\begin{array}{l}-0.0009 \\
(0.0023)\end{array}$ & $\begin{array}{l}-0.0002 \\
(0.0021)\end{array}$ & $\begin{array}{c}0.0106 \\
(0.0025)^{* * *}\end{array}$ & $\begin{array}{c}-0.0008 \\
(0.0023)\end{array}$ & $\begin{array}{l}-0.0002 \\
(0.0021)\end{array}$ \\
\hline Proximity & $\begin{array}{c}0.117 \\
(0.036)^{* * *}\end{array}$ & $\begin{array}{l}-0.020 \\
(0.026)\end{array}$ & $\begin{array}{l}-0.015 \\
(0.027) \\
\end{array}$ & $\begin{array}{l}0.117 \\
(0.036)^{* * *}\end{array}$ & $\begin{array}{l}-0.019 \\
(0.026)\end{array}$ & $\begin{array}{l}-0.015 \\
(0.027)\end{array}$ \\
\hline Density & $\begin{array}{c}0.014 \\
(0.007)^{* *}\end{array}$ & $\begin{array}{c}-0.012 \\
(0.004)^{* * *}\end{array}$ & $\begin{array}{c}-0.014 \\
(0.005)^{* * *}\end{array}$ & $\begin{array}{c}0.014 \\
(0.007)^{* *}\end{array}$ & $\begin{array}{c}-0.012 \\
(0.004)^{* * *}\end{array}$ & $\begin{array}{c}-0.014 \\
(0.005)^{* * *}\end{array}$ \\
\hline Public state or local & $\begin{array}{c}0.034 \\
(0.041) \\
\end{array}$ & $\begin{array}{c}0.035 \\
(0.041) \\
\end{array}$ & $\begin{array}{c}0.034 \\
(0.041) \\
\end{array}$ & $\begin{array}{c}0.020 \\
(0.042)\end{array}$ & $\begin{array}{c}0.018 \\
(0.042)\end{array}$ & $\begin{array}{c}0.018 \\
(0.042)\end{array}$ \\
\hline Corrections officer & $\begin{array}{c}0.003 \\
(0.038)\end{array}$ & $\begin{array}{c}0.003 \\
(0.038) \\
\end{array}$ & $\begin{array}{c}0.003 \\
(0.038)\end{array}$ & $\begin{array}{c}0.003 \\
(0.038)\end{array}$ & $\begin{array}{c}0.003 \\
(0.038)\end{array}$ & $\begin{array}{c}0.003 \\
(0.038) \\
\end{array}$ \\
\hline $\begin{array}{l}\text { Housing price } \\
\text { premium }(\$ 1,000 \mathrm{~s})\end{array}$ & & $\begin{array}{c}0.022 \\
(0.003)^{* * *}\end{array}$ & $\begin{array}{c}0.021 \\
(0.003)^{* * *}\end{array}$ & & $\begin{array}{c}0.022 \\
(0.003)^{* * *}\end{array}$ & $\begin{array}{c}0.021 \\
(0.003)^{* * *}\end{array}$ \\
\hline Inmates per officer & & & $\begin{array}{l}-0.003 \\
(0.004)\end{array}$ & & & $\begin{array}{l}-0.003 \\
(0.004)\end{array}$ \\
\hline $\begin{array}{l}\text { Inmates per officer } \\
\times \text { public corrections }\end{array}$ & & & $\begin{array}{l}-0.011 \\
(0.010)\end{array}$ & & & $\begin{array}{l}-0.007 \\
(0.013)\end{array}$ \\
\hline $\begin{array}{l}\text { Public state or local } \\
\times \text { mild }\end{array}$ & $\begin{array}{c}0.0022 \\
(0.0012)^{*}\end{array}$ & $\begin{array}{c}0.0025 \\
(0.0012)^{* *}\end{array}$ & $\begin{array}{c}0.0029 \\
(0.0014)^{* *}\end{array}$ & $\begin{array}{c}0.0018 \\
(0.0010)^{*}\end{array}$ & $\begin{array}{c}0.0020 \\
(0.0011)^{*}\end{array}$ & $\begin{array}{c}0.0023 \\
(0.0015) \\
\end{array}$ \\
\hline $\begin{array}{l}\text { Public state or local } \\
\times d r y\end{array}$ & $\begin{array}{c}0.0123 \\
(0.0048)^{* *}\end{array}$ & $\begin{array}{c}0.0122 \\
(0.0046)^{* * *}\end{array}$ & $\begin{array}{c}0.0142 \\
(0.0040)^{* * *}\end{array}$ & $\begin{array}{c}0.0183 \\
(0.0043)^{* * *}\end{array}$ & $\begin{array}{c}0.0181 \\
(0.0047)^{* * *}\end{array}$ & $\begin{array}{c}0.0193 \\
(0.0048)^{* * *}\end{array}$ \\
\hline $\begin{array}{l}\text { Public state or local } \\
\times \text { proximity }\end{array}$ & $\begin{array}{c}0.185 \\
(0.111)\end{array}$ & $\begin{array}{c}0.173 \\
(0.117) \\
\end{array}$ & $\begin{array}{c}0.181 \\
(0.114)\end{array}$ & $\begin{array}{c}0.337 \\
(0.173)^{*}\end{array}$ & $\begin{array}{c}0.306 \\
(0.177)^{*}\end{array}$ & $\begin{array}{c}0.3031 \\
(0.177)^{*}\end{array}$ \\
\hline $\begin{array}{l}\text { Public state or local } \\
\times \text { density }\end{array}$ & $\begin{array}{c}0.063 \\
(0.007)^{* * *}\end{array}$ & $\begin{array}{c}0.064 \\
(0.007)^{* * *}\end{array}$ & $\begin{array}{c}0.056 \\
(0.009)^{* * *}\end{array}$ & $\begin{array}{c}0.064 \\
(0.007)^{* * *}\end{array}$ & $\begin{array}{c}0.067 \\
(0.007)^{* * *}\end{array}$ & $\begin{array}{c}0.062 \\
(0.007)^{* * *} \\
\end{array}$ \\
\hline $\begin{array}{l}\text { Joint significance } \\
(p \text {-value })\end{array}$ & $<0.001$ & $<0.001$ & $<0.001$ & $<0.001$ & $<0.001$ & $<0.001$ \\
\hline Mild + interaction & $\begin{array}{c}0.0018 \\
(0.0010)^{*}\end{array}$ & $\begin{array}{c}0.0012 \\
(0.0008) \\
\end{array}$ & $\begin{array}{c}0.0017 \\
(0.0009)^{*}\end{array}$ & $\begin{array}{c}0.0014 \\
(0.0010) \\
\end{array}$ & $\begin{array}{c}0.0007 \\
(0.0007) \\
\end{array}$ & $\begin{array}{c}0.0011 \\
(0.0010)\end{array}$ \\
\hline Dry + interaction & $\begin{array}{c}0.0229 \\
(0.0044)^{* * *}\end{array}$ & $\begin{array}{c}0.0114 \\
(0.0039)^{* * *}\end{array}$ & $\begin{array}{c}0.0140 \\
(0.0041)^{* * *}\end{array}$ & $\begin{array}{c}0.0289 \\
(0.0044)^{* * *}\end{array}$ & $\begin{array}{c}0.0172 \\
(0.0047)^{* * *}\end{array}$ & $\begin{array}{c}0.0192 \\
(0.0051)^{* * *}\end{array}$ \\
\hline $\begin{array}{l}\text { Proximity + } \\
\text { interaction }\end{array}$ & $\begin{array}{c}0.302 \\
(0.135)^{* *}\end{array}$ & $\begin{array}{c}0.154 \\
(0.102)\end{array}$ & $\begin{array}{c}0.166 \\
(0.099)\end{array}$ & $\begin{array}{c}0.455 \\
(0.197)^{* *}\end{array}$ & $\begin{array}{c}0.287 \\
(0.164)^{*}\end{array}$ & $\begin{array}{c}0.288 \\
(0.164)^{*}\end{array}$ \\
\hline $\begin{array}{l}\text { Density + } \\
\text { interaction }\end{array}$ & $\begin{array}{c}0.077 \\
(0.010)^{* * *}\end{array}$ & $\begin{array}{c}0.051 \\
(0.007)^{* * *}\end{array}$ & $\begin{array}{c}0.043 \\
(0.008)^{* * *}\end{array}$ & $\begin{array}{c}0.078 \\
(0.009)^{* * *}\end{array}$ & $\begin{array}{c}0.054 \\
(0.007)^{* * *}\end{array}$ & $\begin{array}{c}0.049 \\
(0.006)^{* * *}\end{array}$ \\
\hline $\mathrm{N}$ & $1,510,381$ & $1,510,381$ & $1,510,381$ & $1,507,178$ & $1,507,178$ & $1,507,178$ \\
\hline
\end{tabular}

Notes: See notes to Tables 3-5. The only difference relative to Table 5 is that only corrections officers are included among public-sector workers. The inmate-officer ratio is demeaned (based on the same population weights used for the regression, and using the same sample), so that the main effects capture the effect at the sample means.

Sources: CPS ORG files, 1994-2005; 2000 Census 5\% sample; inmate-staff ratios are taken from Stephan (2008, Appendix Table 14). 
Table 14: Falsification Test, Wage Regressions with Public SectorAmenity Interactions, for Public Federal Workers

\begin{tabular}{|l|c|c|}
\hline & $\begin{array}{c}\text { Union and nonunion federal } \\
\text { public-sector workers vs. all } \\
\text { private workers }\end{array}$ & $\begin{array}{c}\text { Only union federal public- } \\
\text { sector workers vs. all } \\
\text { private workers }\end{array}$ \\
\hline Mild & $(1)$ & $(2)$ \\
\hline Dry & -0.0004 & -0.0004 \\
$(0.0005)$ & $(0.0005)$ \\
\hline Proximity & 0.011 & 0.011 \\
& $(0.002)^{* * *}$ & $(0.002)^{* * *}$ \\
\hline Density & 0.119 & 0.118 \\
& $(0.037)^{* * *}$ & $(0.037)^{* * *}$ \\
\hline Public federal & 0.015 & 0.015 \\
& $(0.007)^{* *}$ & $(0.007)^{* *}$ \\
\hline Public federal & 0.098 & 0.013 \\
$\times$ mild & $(0.010)^{* * *}$ & $(0.007)^{*}$ \\
\hline Public federal & 0.00004 & -0.0006 \\
$\times$ dry & $(0.0005)$ & $(0.0004)$ \\
\hline Public federal & -0.0058 & -0.0094 \\
$\times$ proximity & $(0.0024)^{* *}$ & $(0.0025)^{* * *}$ \\
\hline Public federal & -0.058 & -0.106 \\
$\times$ density & $(0.044)$ & $(0.046)^{* *}$ \\
\hline N & -0.022 & 0.004 \\
Notes See notes & $(0.009)^{* *}$ & $(0.005)$ \\
\hline
\end{tabular}

Notes: See notes to Tables 3-5. The only difference relative to Table 5 is that only federal workers are included among public-sector workers. The housing cost premia are excluded.

Sources: CPS ORG files, 1994-2005; 2000 Census 5\% sample. 


\section{References}

Albouy, D., 2009. What are cities worth? Land rents, local productivity, and the capitalization of amenity values. NBER Working Paper, \#14981.

BeEson, P.E., 1991. Amenities and regional differences in returns to worker characteristics. Journal of Urban Economics 30, 224-241.

Beeson, P.E., EBerts, R.W., 1989. Identifying productivity and amenity effects in interurban wage differentials. Review of Economics and Statistics 71, 443-452.

Biggs, A.G., 2010a. Are government workers underpaid? No. The American. Washington, D.C.: The American. American Enterprise Institute. Available at http://www.nytimes.com /2010/10/12/opinion/12brooks.html?_r=2\&src=tptw (viewed December 15, 2010).

Biggs, A.G., 2010b. The market value of public-sector pension deficits. Retirement Policy Outlook. Washington, D.C.: American Enterprise Institute. Available at http://www.aei. org/docLib/2010RPOno1g.pdf (viewed December 15, 2010).

BorJas, G.J., 2002. The wage structure and the sorting of workers into the public sector. NBER Working Paper No. 9313.

Blomquist, G., Berger, M., Hoenn, J., 1988. New estimates of quality of life in urban areas. American Economic Review 78, 89-107.

DiSalvo, D., 2010. The trouble with public sector unions. National Affairs 5 (Fall), 3-19. Available at http://www.nationalaffairs.com/doclib/20100918_DiSalvo_pdf\%5B1\%5D.pdf (viewed December 16, 2010).

Edwards, J., Keen, M., 1996. Tax competition and Leviathan. European Economic Review 40, 113-134.

Freeman, R.B., 1986. Unionism comes to the public sector. Journal of Economic Literature $24(1), 41-86$.

Freeman, R.B., Valletta, R., 1988. The effects of public sector laws on labor market institutions and outcomes. In R.B. Freeman and C. Ichniowski, eds., When Public Sector Workers Unionize. Chicago: University of Chicago Press.

Gabriel, S.A., Rosenthal, S.S., 2004. Quality of the business environment versus quality of life: Do firms and households like the same cities? Review of Economics and Statistics $86,538-444$. 
Glaeser, E.L., Kahn, M.E., 2004. Sprawl and urban growth. In J.V. Henderson and J.-F. Thisse, eds., Handbook of Regional and Urban Economics, Vol. 4. Amsterdam: Elsevier.

Gramlich, E.M., 1976. The New York City fiscal crisis: What happened and what is to be done? American Economic Review Papers and Proceedings 66, 415-429.

Gyourko, J., Tracy, J., 1989a. The importance of local fiscal conditions in analyzing local labor markets. Journal of Political Economy 97, 1208-1231.

Gyourko, J., Tracy, J., 1989b. On the political economy of land value capitalization and local public sector rent seeking in a Tiebout model. Journal of Urban Economics 26, 152-173.

Gyourko, J., Tracy, J., 1989c. Local public sector rent-seeking and its impact on local land values. Regional Science and Urban Economics 19, 493-516.

Gyourko, J., Kahn, M., Tracy, J., 1999. Quality of life and environmental comparisons. In E. Mills and P. Cheshire, eds., Handbook of Regional and Urban Economics, Vol. 3. Amsterdam: North Holland.

Henderson, J.V., 1982. Evaluating consumer amenities and interregional welfare differences. Journal of Urban Economics 11, 32-59.

Hellerstein, J.K., Neumark, D., 1999. Wages, productivity, and worker characteristics: Evidence from plant-level production functions and wage equations. International Economic Review 40, 95-123.

Malanga, S., 2010. The beholden state: How public-sector unions broke California. City Journal 20. Available at http://www.city-journal.org/2010/20_2_california-unions.html (viewed April 21, 2012).

Mendelsohn, R., Nordhaus, W.D., Shaw, D., 1994. The impact of global warming on agriculture: A Ricardian analysis. American Economic Review 84, 753-751.

O'Brien, K.M., 1992. Compensation, employment, and the political activity of public employee unions. Journal of Labor Research 13, 189-203.

Rappaport, J., SACHs, J., 2003. The United States as a coastal nation. Journal of Economic Growth 8, 5-46.

Roback, J., 1982. Wages, rents, and the quality of life. Journal of Political Economy 90, 1257-1278.

Rose, H., Sonstelie, J., 2010. School board politics, school district size, and the bargaining 
power of teachers unions. Journal of Urban Economics 67, 438-50.

Rosenthal, S.S., Strange, W.C., 2004. Evidence on the nature and sources of agglomeration economies. In J.V. Henderson and J.-F. Thisse, eds., Handbook of Regional and Urban Economics, Vol. 4. Amsterdam: North Holland.

Schmitt, J., 2010. The Wage Penalty for State and Local Government Employees. Washington, D.C.: Center for Economic and Policy Research.

Stephan, J., 2005. Census of State Correctional Facilities. Washington, D.C.: U.S. Department of Transportation, Office of Justice Programs.

VISSER, J., 2006. Union membership statistics in 24 countries. Monthly Labor Review 129, 38-49.

Wilson, J.D., 1999. Theories of tax competition. National Tax Journal 52, 269-304.

Zax, J., ICHniowski, C., 1988. The effects of public sector unionism on pay, employment, department budgets, and municipal expenditures. In R.B. Freeman and C. Ichniowski, eds., When Public Sector Workers Unionize. Chicago: University of Chicago Press. 


\section{Footnotes}

*We thank Rainald Borck, Kitt Carpenter, Robert Inman, Albert Solé Ollé and seminar participants at several universities for helpful comments.

${ }^{1}$ See, for example, http://reason.org/studies/show/public-sector-private-sector-salary, and and http://www.prisoncensorship.info/archive/etext/agitation/prisons/campaigns/ca /caprisoncrat.html (all viewed December 15, 2010).

${ }^{2}$ See, for example, http://www.post-gazette.com/pg/10164/1064943-373.stm and http://blog.nj.com/njv_editorial_page/2010/02/post_7.html (both viewed December 15, 2010).

${ }^{3}$ See, for example, http://www.northshoreoflongisland.com/Blog-31542.112114-6239.112114Yes-School-Administrators-and-Teachers-are-Vastly-Overpaid.html, http://politics.usnews.com/opinion/mzuckerman/articles/2010/09/10/public-sectorworkers-are-the-new-privileged-elite-class.html, and http://www.nytimes.com/2010/10/12/opinion/12brooks.html?_r=2\&src=tptw (all viewed December 15, 2010)

${ }^{4}$ Similar figures are reported for 2009 in Schmitt (2010).

${ }^{5}$ Gramlich (1976) argues that the large sizes of public-sector work forces, when amplified by sympathetic friends and relatives, guarantees substantial political influence. He notes that "there are now about 450,000 full and part-time city government employees in New York City. If each was married, lived in the city, and had one close friend or relative who would vote alike on city issues, conceivably 1,350,000 votes, 30 percent of the entire voting age population and roughly half of the probable number of voters, could be marshalled in favor of making some strategic concession to, or dealing leniently with, unions."

${ }^{6}$ The data are explained in more detail in the notes to the figure, and later in the paper.

${ }^{7}$ The resulting emigration might be expected to depress land values in regions with high rentseeking. Gyourko and Tracy (1989b,c) test for such an effect and find empirical support for it. Their approach is discussed further in section 2.3 below.

${ }^{8}$ For additional studies, see Albouy (2009), Beeson (1991), Beeson and Eberts (1989), Gabriel and Rosenthal (2004), Gyourko and Tracy (1989a), Gyourko, Kahn and Tracy (1999) and Henderson (1982). 
${ }^{9}$ Since public-sector workers exploit the mobility of private-sector workers in the process of rent-seeking, making them mobile as well is theoretically impractical. Presumably, however, job stability in the public sector leads to much lower interregional mobility for these workers than for private-sector workers, making our assumption not unrealistic.

${ }^{10}$ Since the number of public-sector workers is fixed in the model, the empirical analysis focuses only on public-sector wages and not on employment levels. Putting the model aside, there is no standard empirical approach that one could adapt for identifying differences in publicsector employment across states associated with rent-seeking.

${ }^{11}$ If the amenity were instead $g_{i}$ and its contribution to quasi-linear utility equal to $t\left(g_{i}\right)$, a redefinition that sets $a_{i}=t\left(g_{i}\right)$ would yield (1).

${ }^{12}$ The marginal product could instead depend on a nonlinear function of the amenity, but suitable redefinition would yield the linear additive relationship (see footnote 10). On another issue, note that the production amenity could reduce costs rather than increase worker productivity. For example, suppose that heating and cooling cost per worker is given by a function $t\left(h_{i}\right)$, where $h_{i}$ is a measure of climate unpleasantness. Then, with this cost subtracted off from the marginal product in measuring the worker's contribution, the wage would equal $f^{\prime}\left(L_{i}\right)-t\left(h_{i}\right)$. This expression can be written as $f^{\prime}\left(L_{i}\right)+b_{i}$ by suitable redefinition of the climate amenity, matching the productivity formulation.

${ }^{13}$ This formulation assumes that the consumption and production amenities are positively correlated, with an increase in $A$ generating both consumption and production benefits. The less natural case where a region's features yield consumption benefits but reduce worker productivity can be handled by a reformulation of the model. To capture this case, $\alpha$ would be negative, so that $b_{i}=\alpha A$ is negative while $a_{i}=(1-\alpha) A$ remains positive.

${ }^{14}$ It can be shown that the second-order conditions for the maximization problem are satisfied.

${ }^{15}$ Note that, after rearrangement, condition (7) requires the elasticity of $L_{1}$ with respect to $R_{1}$ to equal -1 .

${ }^{16}$ Since the right-hand side of $(18)$ is less than $2 / 3$, the weaker condition $\bar{L}>M=(1 / 2)(2 M)$ (indicating that $\bar{L}$ exceeds half of the total public-sector work force) actually suffices. The stronger form of the sufficiency condition is needed, however, when housing consumption is added to the model, as seen below.

${ }^{17}$ The private-sector wage increase in region 1 is now proportional to $-f^{\prime \prime} \partial L_{1} / \partial A+\alpha=$ $-f^{\prime \prime} / 6 g^{\prime}+\alpha=\alpha-\lambda / 6$. As a result, the regional wage difference is proportional to $(\alpha-$ 
$\lambda / 6)-\lambda / 6=\alpha-\lambda / 3$. Since this expression is less than unity, the rent-per-worker difference will exceed it when $2 \bar{L} / 3 M>1$, as before.

${ }^{18}$ If public workers were also to consume land, then a change in rent extraction would affect their utility via the impact of $L_{1}$ on the $h\left(L_{1}\right)$ term, which would be added to (20). This additional consideration would require a new version of the above analysis, possibly changing some of the results. In addition, to bring the model fully in line with the Roback tradition, firms would also be users of land. In this case, the market-clearing conditions would include this land usage, and a zero-profit condition would be added for each region. These extra conditions would be needed to determine the quantities of land used in production.

${ }^{19}$ To understand their approach, note that, when housing is incorporated in the model, (20) involves subtraction of a housing price term (equal to $s^{\prime}\left(1 / L_{i}\right)$ ) on each side of the equation. Holding amenities fixed, an exogenous increase in $R_{1}$ then leads to a decrease in price as $L_{1}$ falls in response to greater rent-seeking (recall $s^{\prime \prime}<0$ ). Gyourko and Tracy $(1989 \mathrm{~b}, \mathrm{c}$ ) test for the resulting inverse relationship between housing prices and rent-seeking, using a measure of union influence as a proxy for $R_{1}$.

${ }^{20}$ Since the presence of housing chokes off migration sooner when $A$ rises, the decline in $f^{\prime}\left(L_{1}\right)$ is not as large, keeping the private-sector wage $\left(f^{\prime}+\alpha A\right)$ from declining even when $\alpha$ is relatively small. In the absence of housing, however, a larger decline in $f^{\prime}$ occurs, which more easily dominates the productivity gain from the amenity, leading to a wage decrease. Therefore, when housing is absent, a decline in the wage can occur in the presence of a larger productivity effect from the amenity (equivalently, a smaller amenity consumption component - a smaller $\alpha$ ) than with housing in the model. In other words, when housing is absent, the consumption component of the amenity does not need to be as large to generate a wage decline as when housing is present.

${ }^{21}$ Another testable prediction of the model is that taxes rise with a region's amenity level in order to support higher rent extraction. However, a credible test of this prediction would need to hold public-good levels constant since the model's prediction of a uniform $z$ level across regions is not realistic. This difficulty, combined with the fact that the test would only rely on a simple cross section at the state level, limits the appeal of such an exercise. In contrast, for our analysis of wages, we study the difference between public-sector and private-sector wage differentials associated with amenities, and-as discussed below-the private-sector wage differentials capture state-level differences that may be correlated with amenities.

${ }^{22}$ Elementary and secondary school teachers are by far the largest occupation in local government, and elementary and secondary school teachers and "bailiffs, correctional officers, and jailers" (all of which we group under "corrections officers") are the second and third largest occupations in state employment (after post-secondary teachers); see Schmitt (2010). We also focus on corrections officers and elementary and secondary school teachers because their 
pay is often prominent in public debate.

${ }^{23}$ Elementary and secondary school teachers are defined based on the following Census of Population occupational codes: for 2002 and earlier (1990 Census codes), teachers in kindergarten or pre-kindergarten (155), elementary school (156), secondary school (157), or special education (158); and for 2003 and after (2002 Census codes), preschool and kindergarten teachers (2300), elementary and middle school teachers (2310), secondary school teachers (2320), and special education teachers (2330). Correction officers are defined using the same Census codes as follows: for 2002 and earlier (1990 Census codes), sheriffs, bailiffs, and other law enforcement officers (423), and correctional institution officers (424); for 2003 and after (2002 Census codes), first-line supervisors/managers of correctional officers (3700), and bailiffs, correctional officers, and jailers (3800). Inspection of the share of the workforce in these two occupation groups as defined indicated that the definitions were consistent across the change in the data between 2002 and 2003.

${ }^{24}$ See http://www.census.gov/hhes/migration/ (viewed April 22, 2012).

${ }^{25}$ We thank Jed Kolko for supplying us with these estimates.

${ }^{26}$ We do not control for occupation because many occupations exist largely in only the private or only the public sector, and even when they do exist in both sectors, they may be quite different. Thus, occupation controls are not necessarily human capital controls, and could potentially capture difference between private- and public-sector workers instead. Below, however, we do look at results for two specific occupations that constitute large shares of the public sector: teachers and corrections officers.

${ }^{27}$ Note that the table reports results for specifications including the housing-price premium, in which case the main effects of the amenities are more reflective of consumption amenities. In some cases (most notably, perhaps, for workers with a Bachelor's degree), the estimated main effects of the amenities do not replicate the negative estimates found for the full sample. However, in specifications excluding the housing-price premium, the estimated coefficients of the main effects for most of the amenities were consistently positive, as in Table 5, suggesting that the value of these amenities on the consumption side may vary across different types of workers. Regardless, the estimated public-sector/amenity interactions were very similar when the housing-price premium was excluded.

${ }^{28}$ These are the differences in the public-sector vs. private-sector wage differential. The overall wage difference for public-sector workers between two states would be this difference plus the main effect of the amenity, which would be computed by applying the amenity difference to the estimates in the last four rows of Table 5. Thus, for example, for Proximity, the implied differential would be 7.7 percent-less than the 10.2 percent figure because the main effect of this amenity (in the regression controlling for housing prices) is negative. 
${ }^{29}$ Note that the estimates correspond to those in columns 5 and 7 from those tables. The housing price premium also varies only at the state level, and hence there is no difference between the specification with and without this premium included, once the state fixed effects are added.

${ }^{30}$ We wanted to use data from prior to the sample to reduce the likelihood of reverse causality. Taking our model seriously, in states where public-sector workers can extract rents because of high amenities, public-sector unions likely work harder to support the political party (presumably Democrats) that enables them to extract rents. Recall that the 1992 election also included Ross Perot, who received substantial vote shares in many states.

${ }^{31}$ Note that the Dukakis vote share is not associated with higher relative public-sector wages, while the Clinton vote share is.

${ }^{32}$ Our understanding is that most teachers (except some in prisons and some special needs teachers) are local-government employees. However, given the heavy involvement of state government with education, many teachers may report themselves as state employees.

${ }^{33}$ In the latter case, we are not addressing the potential endogeneity of student-teacher ratios, and the results must just be interpreted as asking whether the partial correlations between public-sector wage differentials and amenities remain the same when the student-teacher ratio is partialed out.

${ }^{34}$ See http:/www.opm.gov/oca/09tables/locdef.asp (viewed December 30, 2010).

${ }^{35}$ The negative point estimates could indicate that federal pay differentials do not fully reflect private differentials.

${ }^{36}$ In Table 14, the house price premia are excluded. Their inclusion has no effect on the results. 